\section{Intersections}

Canadian Journal of Music

Revue canadienne de musique
Intersections CANADIAN JOURAL OF MUSIC
REVUE CANADIENEE DE MUSIOUH

\title{
"A Confusion of Glory": Orthodox Visitors as Sources for Muscovite Musical Practice (Late 16th-mid 17th century)
}

\section{George-Julius Papadopoulos et Claudia R. Jensen}

Volume 26, numéro 1, 2005

URI : https://id.erudit.org/iderudit/1013241ar

DOI : https://doi.org/10.7202/1013241ar

Aller au sommaire du numéro

Éditeur(s)

Canadian University Music Society / Société de musique des universités canadiennes

ISSN

1911-0146 (imprimé)

1918-512X (numérique)

Découvrir la revue

Citer cet article

Papadopoulos, G.-J. \& Jensen, C. R. (2005). "A Confusion of Glory": Orthodox Visitors as Sources for Muscovite Musical Practice (Late 16th-mid 17th century). Intersections, 26(1), 3-33. https://doi.org/10.7202/1013241ar
Résumé de l'article

Les voyageurs orthodoxes en Russie, grecs ou autres, comptent parmi les plus importants témoins au fait des pratiques de chants liturgiques moscovites. Cet article étudie plusieurs sources grecques des années 1600 : un poème et un mémoire de l'archevêque Arsenios d'Elasson (1550-1626) ; un poème de Matthaios Koletzides décrivant les événements en relation avec le Faux Dmitrii (1606) ; enfin, un rapport du voyage à Moscou entrepris par Théophane, Patriarche de Jérusalem (1619). Nous avons également pris en considération la longue narration de Paul d'Aleppe, qui accompagna le Patriarche Makarios d'Antioche à Moscou (dans les années 1650 et 1660). Toutes ces sources représentent de riches exemples des échanges permanents entretenus entre les chanteurs orthodoxes russes et étrangers pendant cette période.
Copyright @ C Canadian University Music Society / Société de musique des universités canadiennes, 2006
Ce document est protégé par la loi sur le droit d'auteur. L'utilisation des services d’Érudit (y compris la reproduction) est assujettie à sa politique d'utilisation que vous pouvez consulter en ligne.

https://apropos.erudit.org/fr/usagers/politique-dutilisation/ 


\section{"A Confusion OF GLORY": ORTHOdoX Visitors as SOURCES FOR MUSCOVITE MUSICAL Practice (Late 16Th-Mid 17Th Century)}

George-Julius Papadopoulos and Claudia R. Jensen

The English party that arrived in Moscow in February 1664 was stunned by their reception in the Kremlin. Their scribe, Guy Miege, struggled to describe his impressions as the delegates embarked on their first audience with Tsar Aleksei Mikhailovich (r. 1645-76). After passing through numerous ranks of the Tsar's soldiers and through a staggering series of courtyards and passages, the Englishmen finally entered the royal reception hall. "And here," Miege writes, "it was we were like those who coming suddainly out of the dark are dazled with the brightnes of the Sun: the splendor of their jewels seeming to contend for priority with that of the day; so that we were lost as it were in this confusion of glory."

Miege's awe-struck tale is typical, for the Muscovite authorities clearly aimed-quite successfully-at overwhelming their diplomatic visitors with the wealth and grandeur of their court. Yet in many ways, Muscovite culture discouraged outsiders from comprehending the central, core events of daily life: the roles and rituals of the Orthodox Church. Although the lives of Muscovy's secular leaders were intricately intertwined with their religious devotions and duties, even the best informed foreigners were able to glimpse these activities only from afar, for visitors were generally forbidden even to enter Russian churches, let alone to participate in its rituals. Some travelers resorted to subterfuge. The Saxon Adam Schleussing, for example, who visited Russia in 1684, suggested that visitors might circumvent the prohibition on entering churches, either by visiting the private chapel of some wealthy Muscovite or simply by disguising oneself in Russian clothing and going in under cover. He presumably speaks from experience, but nevertheless has little to report concerning Orthodox religious practice-and nothing at all to say about liturgical music (Lapteva 1970:117).

Other visitors did their best under the circumstances, peeping into churches or monasteries when they could and delivering bits of wisdom to their Western readers. In some cases their observations are useful, as is, for instance, the account by Johan Sparwenfeld, a member of a Swedish delegation to Muscovy in the 1680s. On their way to Moscow, Sparwenfeld's party visited the large and important Iverskii-Valdaiskii Monastery, not far from Novgorod, founded in

1 Miege 1669, 147-48. The English ambassador had his audience with the Tsar on 11 February, and the party left in June. 
1653 by Patriarch Nikon. Despite the fact that the monastery was relatively open in its cultural orientation (Sparwenfeld says that some of the monks knew Latin and that most were Belorussian or Ukrainian), they were nevertheless wary of admitting the curious visitors. After denying their application for admission, the porter "asked us not to blame the archimandrite, as he has been much criticized in Moscow for having been very complaisant in his dealings with foreigners," explains Sparwenfeld (2002, 98-99). Later the visitors observed a service from the doorway, and Sparwenfeld offers interesting, if admittedly uninformed, comments about the music he heard: "Concerning the service I cannot say much as I did not understand it ... every time the priest had sung something before the altar a choir behind the altar ... responded and it resounded with the beautiful harmony of five or six parts. In this way they answered each other a few times, something from the litany and Hear us, Lord our God" (2002, 102-03, 105). Sparwenfeld's doorway observations thus offer welcome, if fairly non-specific, confirmation of the monastery's modern musical approach, employing the Western-style part singing called partesnoe penie (from the Latin partes), which had been imported via Ukraine beginning in mid-century. ${ }^{2}$ Other accounts hint at some sort of interaction between the liturgical singers and foreign visitors. Samuel Collins, the English physician to the Tsar who resided in Moscow throughout the 1660s, included in his published memoirs a text which he had had "prick't down by one of the Patriarchs Choristers" $(1671,34)$.

There are exceptions to these restrictions, however, for a select few of the travelers to the Tsar's realm were indeed able to contribute informed commentary on Orthodox musical practice. These valuable witnesses were visiting Orthodox clerics, who were not only most welcome to attend services in Russia, but were able accurately to report on what they had heard or, in some cases, on what they had participated in themselves. ${ }^{3}$ Their observations are important, for the late sixteenth and the seventeenth centuries witnessed enormous changes in Russian liturgical singing. New chant styles emerged, along with new approaches to notation; polyphony of several different types became increasingly common; and musical influences from the West-compositional styles,

2 There is a good survey of the musical references to the Iverskii-Valdaiskii Monastery in Keldysh 1983, 171-72. Sparwenfeld's account supports other evidence of the partesnoe penie promoted by Patriarch Nikon at the Iverskii Monastery and promulgated in general throughout Muscovy by Ukrainian singers and composers imported specially for the task (see also the discussion below). In preparing for a visit he and the Tsar were to make to the Iverskii Monastery in 1657, for example, the Patriarch requested the best singers in the new partesnoe style ("po portesu"); a few years later, Nikon ordered the archimandrite there to send polyphonic pieces in the new style to the New Jerusalem Monastery. These sources are also summarized in Kharlampovich 1968, 318.

3 Even in the case of visiting Orthodox clerics, however, there was some skepticism on the Russians' part. In his account of his trip to Moscow in the 1650s, accompanying Patriarch Makarios of Antioch, archdeacon Paul of Aleppo writes: "We were told also, that formerly, when any Head of the clergy from Greece, or any Patriarch, came into Russia, this nation did not permit them to perform mass in their churches, thinking them defiled from their intercourse with the Turks; nor was any Greek merchant allowed even to enter their churches, for fear they should be defiled, as they considered him to be ... Since the time of their being visited by Jeremiah, Patriarch of Constantinople [in 1589], Theophanes, Patriarch of Jerusalem [in 1619], and others, and mixing in their society, they have become familiarised with strangers ..." (Balfour 1829-36, 1:382). See also the discussion of the Russians' view of Greek clerics in Kapterev 1895:34ff. 
theoretical vocabulary, and notation-were developed intensively. This was, in short, a tremendously energetic and vital period, and the rare insider accounts by Orthodox clerics provide an indispensable perspective.

We shall focus on two groups of such accounts, covering two important periods in Russian history. The first group includes a cluster of reports written by Greek visitors to Russia, beginning in the late sixteenth century and continuing through the Time of Troubles and the subsequent establishment of the Romanov dynasty, in 1613. This date marks the end of the Troubles (which had devastated Russian society through invasions from without and civil war from within), and the beginning of the solidification and expansion of the Muscovite state over the course of the century and beyond. Our sources from this period include two works written by Archbishop Arsenios of Elasson: a long poem describing the creation of the Russian patriarchate in 1589 and an autobiographical narrative of Arsenios's subsequent career in Muscovy, where he continued to work until his death in 1626 . We also consider a poem by hieromonk Matthaios Koletzides, who witnessed the procession of the Polish bride-to-be of the so-called False Dmitrii when she came to Russia in 1606. In addition, we include a slightly later work, an anonymous report of an alms-collecting trip to Moscow made by Theophanes, Patriarch of Jerusalem, to Moscow in 1619. In the second half of this article, we turn to a detailed travel diary from the middle of the seventeenth century written by Paul, Archdeacon of Aleppo, an Arabic-speaking Orthodox cleric who traveled to Moscow with Patriarch Makarios of Antioch in the mid-1650s and again in the 1660s. Paul's observant and authoritative account provides some unexpected continuity with the earlier Greek writings, and introduces issues crucial to an appreciation of the layered cultural contexts for Muscovite music of mid-century.

Archbishop Arsenios's accounts are particularly valuable, for they reflect his active engagement in Muscovite religious and political events over a span of some forty years. ${ }^{4}$ Arsenios (1550-1626) came from a family of clerics: his father was a priest; his mother (who also belonged to a family that had produced some high ranking clerics) became a nun after her husband's death; and all four

4 The primary sources on Arsenios are Demetrakopoulos 1984 and Dmitrievskii 1899; the latter contains a parallel Greek-Russian edition (or, in places, only a Russian translation) of Arsenios's memoirs and is reprinted in Liberman, Morosov, and Shokarev 1998, 163-210. Arsenios's poem, in Manuscript 337 of the Turin Library (destroyed by fire in 1904), has been published several times: it appeared first in Pasinus, Rivautella, and Berta 1749, in a mediocre Latin translation (according to Zampelios 1983,25) in which the title Kópoi kai Diatribē was rendered as Iter et Labores (the reverse order would have been correct); the Latin translation was reprinted in Wichmann 1820. The Greek text also appears in Zampelios 1983 and Sathas 1979, Appendix, and a Russian translation is in Pitirim 1968. (Important new work on Arsenios will appear in the near future. In a phone conversation in fall 2005, Professor Demetrakopoulos informed us that he was working on an updated reprint of his book, also to include a critical edition of Arsenios's poem. Moreover, he has recently completed an edition of Arsenios's memoir, based on Dmitrievskii's handwritten copy of the Greek text from the lost manuscript Soumela 85. According to Professor Demetrakopoulos, the Russian scholar B. L. Fonkich is working on a new Russian translation of Arsenios's memoir. We wish to thank Professor Demetrakopoulos for this valuable information.) Other sources offering brief surveys of Arsenios's life and works, in addition to the detailed discussion in Demetrakopoulos 1984, 29-86, include Zilitinkevich 1992; Demetrakopoulos 1981; and Alexandropoulou 1989-1990. Arsenios's activities in Russia as reflected in manuscript sources are discussed in Fonkich 1977, reviewed in Waugh 1981. 
of his brothers were also ordained. After his initial schooling in the Holy Scriptures, Arsenios received his general education at a school in Trikke (Trikala) which had been founded by Hieremias, Metropolitan of Larissa. Arsenios studied there from about 1568-69 to 1572, and during that time he was ordained as a deacon by Metropolitan Hieremias, who, in 1572, was elected Patriarch of Constantinople. Several years later, Hieremias invited Arsenios to come to Constantinople, and Arsenios, who had been ordained as a priest just a few days prior to his arrival in the city, remained there for over four years as patriarchal vicar of the Great Church of the Most Blessed [Virgin Mary] in the patriarchate. In 1584, Arsenios was consecrated Archbishop of Elasson and Demoniko, and he left Constantinople to take up residence on the Greek mainland. He was summoned back to Constantinople after only a year, and sometime in June 1585 the new Patriarch, Theoleptos, sent Arsenios to Moscow as a patriarchal exarch, in charge of a small delegation carrying holy relics to Tsar Fedor Ivanovich (r. 1584-98) and collecting alms from the Russian ruler. ${ }^{5}$

On his return from Moscow in May 1586, Arsenios stopped in L'viv, where there was a thriving Greek Orthodox merchant community, and where the Orthodox brotherhood (bratstvo) at the Church of the Dormition had founded a school that was currently in desperate need of a teacher. Arsenios heeded their urgent plea to remain in the city, working as the school's first teacher of Greek. His curriculum is preserved in his Greek Grammar (Grammatike) , which was later printed at the Brotherhood's press in $1591 .^{6}$ In May 1588, still in L'viv, Arsenios received a letter from Hieremias, who had been elevated to the patriarchal throne for the third time, requesting his former pupil to accompany the patriarchal party on a trip to Moscow. This journey, too, was aimed at collecting donations, a necessary task for the Greek Church during the difficult times of Ottoman rule, and particularly necessary in order to alleviate the patriarchate's heavy indebtedness, for which Pachomios and Theoleptos, the interim patriarchs, were primarily responsible. Metropolitan Hierotheos of Monemvasia, who accompanied the group heading for Moscow, was one of several senior hierarchs who fanned out across the Orthodox world as part of this effort, which, in addition to Muscovy, included Iberia, Cyprus, and Alexandria. ${ }^{7}$ But why, then, did

5 This was one of a series of alms-collecting trips, increasing in frequency and rank, that Greek clerics made to Muscovy; see the evaluation in Gudziak 1998, 89-103, where he also provides a short summary of Arsenios's biography on pp. 149-50.

6 Isaevych 1966, 118 and 129 mentions Arsenios's role in this important cultural and educational institution (which is also significant for its musical practice; see below). There is more substantial discussion of the curriculum of the L'viv Brotherhood and Arsenios's role there in Gudziak 1998, 143-52, and see also Demetrakopoulos 1984, 73-80 and 179-80. The Prologue to Arsenios's Grammar is found ibid., 208-09; see also figures 24-26 and Gudziak 1998, 142. On the Russian court's expression of some disapproval at Arsenios's decision to stop in L'viv, see Gudziak 1998, 177.

7 Gritsopoulos 1965 gives biographical information on Hierotheos of Monemvasia. He believes that Hierotheos may have visited Russia again in 1594, and his presence there in 1596 is documented; Hierotheos most likely met with Arsenios at these times. We have no information regarding his whereabouts after 1596. Modern scholarship agrees that Hierotheos, to whom several other works are credited, also wrote an important sixteenth-century source, the Chronographia [Chronicle] of Pseudo-Dorotheos. This compilation, based on several different histories, was first published in Venice in 1631 and reprinted in 1637. For Greek sources dealing with Pseudo-Dorotheos's chronicle from different scholarly perspec- 
Patriarch Hieremias feel it necessary to travel to Russia in person? His emissary, Hierotheos, was a well-respected and very experienced hierarch who could be relied upon to represent the Patriarch's interests fully, and Arsenios had already had important experience in Moscow as well as in L'viv. The Patriarch's decision to undertake such a journey himself may have been influenced not only by the critical need for funds, but also by the long-standing personal ties among the three men. ${ }^{8}$ Hierotheos was one of the Patriarch's oldest associates and indeed one of his teachers, a relationship that explains Hierotheos's staunch support of the twice-deposed Patriarch during the interim periods. Arsenios, in his turn, had been educated under the auspices of the future Patriarch, and his career in Constantinople had been shaped by this association. This 1588 journey to Moscow, then, was a culmination of decades of shared experiences, and the three representatives from Constantinople-Patriarch Hieremias with Metropolitan Hierotheos and Archbishop Arsenios-were bound by strong personal relationships, based on formative influences spanning the three generations. ${ }^{9}$

The patriarchal party reached the Russian border at Smolensk in 1588 and was escorted to Moscow by a specially-dispatched royal entourage. Hieremias,

tives, see Oikonomidou 1959; Zachariadou 1962; Stanitsas 1985-86; Kechagioglou, 2001; and Staurakopoulou 2003, especially 47-52 and 53-56. Gudziak 1995:221-25 gives English translations of excerpts relating to Hieremias's trip (from Sathas 1979), and see also the comprehensive Russian study in Lebedeva 1968. Gudziak 1998, 31-34, outlines Hieremias's biography, with a portrait of the Patriarch on p. 154

8 Many extant letters from this period, addressed to the hierarchs in general, to the people directly, and to the hierarchs of the West and the Peloponnesus, attest to Hieremias's active campaigning in order to raise the funds necessary to alleviate the Patriarchate's terrible financial situation (Sathas 1979, Appendix). The date of Hieremias's death is generally placed between 1594-96 (Karmiris 1965 and Sathas 1979).

${ }^{9}$ Medlin and Patrinelis 1971, 34, conclude that the "real purpose of his [Patriarch Hieremias's] visit to Moscow is still a historical riddle." There may be another side to this "riddle," for Hieremias initially accepted the Russians' offer to be the first Patriarch of Moscow and all Russia (as recorded by Arsenios and Pseudo-Dorotheos [Hierotheos]), suggesting at least that he had come to Moscow consciously prepared to face such a possibility. Demetrakopoulos $1984,87, \mathrm{n} .40$, even speculates that, exhausted by the situation in Constantinople, Hieremias might have made the decision to travel to Moscow in order to retire there or even to become the Patriarch of Moscow himself. Pseudo-Dorotheos claims that, when the Russians initially approached the Patriarch to inquire about establishing a Moscow Patriarchate, he replied that this could be done only with the approval of an Ecumenical Synod (Sathas 1979, Appendix, 21). Upon being approached again unofficially, Hieremias conceded and insisted on remaining there, despite Hierotheos's vehement arguments to the contrary. What saved the situation is the fact that the Russians apparently did not really wish to have Hieremias as head of their Church, and so he finally agreed to consecrate as Patriarch someone who would be elected by a council from a list of candidates and who would meet with the Tsar's approval. A detailed discussion is in Gudziak 1998, 168-87, where he emphasizes the primacy of alms collection in Hieremias's trip, noting that there is no mention of any plans to create a Muscovite Patriarchate at this time. The Muscovites' request, however, could not have come as a surprise, as the issue had been raised only a few years earlier, during the visit of Patriarch Ioakeim of Antioch, the first of the Eastern Patriarchs to visit Muscovy (1586); see Makarii 1883-1903, 10:7-12. Gudziak 1995:210-11 and 1996:234-35 and 241-42, n. 50 addresses this issue briefly, as does Konstantinidis 1965. As Makarii notes, Patriarch Ioakeim's treatment in Moscow (including Metropolitan Dionisii's violation of rank in blessing the Patriarch before the higher-ranking Patriarch blessed him) was no simple ecclesiastical or diplomatic blunder, but rather a none-too-subtle signal of Muscovite aspirations. Indeed, when the Russian patriarchate was established a few years later, the Muscovites wanted it to be ranked third, ahead of those of Antioch and Jerusalem, a goal they did not achieve (Makarii 1883-1903, 10:45ff.); this reflects the alms-giving patterns long established by the Russians, whose largesse was concentrated on Constantinople, at the expense, particularly, of Antioch (Gudziak 1998, 158). 
Hierotheos, and Arsenios were the three co-signatories of the patriarchal edict promoting Iov, the former Metropolitan of Moscow, to the newly established patriarchal throne of Moscow and all Russia. The official ceremony took place in January 1589, and Hieremias and his suite left Moscow in May, finally arriving back in Constantinople in the spring of $1590 .{ }^{10}$ Arsenios, however, had decided yet again to remain in Russia, and he requested, and was granted, permission by Tsar Fedor to stay in Moscow. He lived there for the rest of his life, actively engaged in the Muscovite Church and its politics until his death in 1626.

The highlights of the early portions of Arsenios's accounts are his descriptions of the ceremonies surrounding Metropolitan Iov's elevation to the newly created patriarchal seat. ${ }^{11}$ Arsenios's most detailed accounting of this event is in his poem, written in vivid and direct language that employs imagery common to contemporary folk poetry, and describing the important events in faraway Muscovy in a medium and through language readily accessible by everyday readers. Although the poem is highly stylized, it proves to offer a largely accurate picture of the impressive liturgical singing that sounded throughout the ceremonies. The Muscovite singing ensembles, attached to the Tsar and to important church hierarchs and monasteries, were well-established by this time, and some were quite large. ${ }^{12}$ Tsar Ivan IV (Ivan the Terrible, r. 1533-84) employed between $25-30$ singers in the 1570 s and early 1580 s, and the various church hierarchs associated with the city of Novgorod, where there was a strong local singing tradition, had had about the same number of singers in the middle of the century (Zvereva 1987:126-28 and n. 21). Arsenios's description of the great ceremony of the new Patriarch's installation, along with the preserved Russian documents, thus provides a vivid picture of how these established choirs interacted with visiting singers in one of the most important religious events ever staged in Moscow.

10 Immediately upon his return to Constantinople, Hieremias called a Great Synod to confirm the establishment of the Moscow Patriarchate and ratify the consecration and elevation of Iov as Patriarch. This official Act was signed by the Patriarchs of Constantinople, Antioch, and Jerusalem, and by more than eighty archpriests. The document was contained in a Synodic Tome of May 1590, promptly delivered to Moscow, and is reprinted in Germanos 1945, 33-34. There was yet another Synodic Act-composed in February 1593 and again handed over to the Russian authorities-but it adds nothing substantial to the 1590 Act (aside from the fact that it now bears the signature of Meletios Pegas, newly elected Patriarch of Alexandria, but omits the signature of the Patriarch of Antioch Ioakeim). Sathas 1979, Appendix, 82-98, publishes the text of the 1593 Synodic Act along with the letters that were subsequently sent to the parties involved (Patriarch Iov, Tsar Fedor, Boris Godunov, and Tsaritsa Irina), to relay the outcome of the deliberations.

11 Among the voluminous literature on the subject, see Nikolaevskii 1897; Makarii 1883-1903, vol. 10 (esp. pp. 34-39, where the installation ceremonies are described); and the published primary sources listed below; other sources are surveyed in more detail in Gudziak 1998, especially chapter 11, and in 1996. Demetrakopoulos 1984, 85-86 and 137, notes that Arsenios certainly had an agenda, concluding that his poem's primary aim was "to defend and praise Hieremias's stance," and of course to relate to his Greek-speaking readership the heroic effort of their Orthodox leader to protect the Mother Church. Gudziak 1995:214 also notes that Arsenios, "having become a client of Muscovy, had every reason to describe the establishment of the patriarchate in laudatory terms," and therefore glossed over some of the disagreements among members of the Greek party concerning the momentous business of creating the new patriarchal seat.

12 Excellent recent studies on the choirs are in Parfentev 1991; Zvereva 1987; and Zvereva 1989. 
There was singing at nearly every step of the ceremony itself, which took place on Sunday, 26 January 1589 at the Uspenskii Cathedral in the Kremlin. ${ }^{13}$ Each of the principals had a special singing ensemble: Tsar Fedor Ivanovich was represented by the gosudarevy pevchie d'iaki [sovereign's singing clerics]; each of the two Patriarchs was accompanied by his own ensemble; and there were additional singers associated with other important hierarchs, for example the newly elevated Aleksandr, Metropolitan of Novgorod. The Greek and Russian singers participated fairly equally in the proceedings. Following a general sounding of all of the bells (blagovest), Patriarch Hieremias entered the cathedral, walked up to the pulpit, and was robed to the accompaniment of his Greek singers, who chanted a hymn to the Cross (slavnik krestu) and then, as the Russian sources say, an "Ispolaeti despota" (loosely transliterated from the Greek benediction "Eis pollá étē, déspota"; in Russian, this is called a mnogoletie, or Many Years, although the sources frequently refer only to the transliterated form). ${ }^{14}$ Tsar Fedor then entered with a large suite, and the sovereign's singers met him with a mnogoletie. After the prayers and speeches associated with the elevation ceremony, (and described in both Arsenios's poem and in the Russian documents), Divine Liturgy was celebrated by both Patriarchs. At this point, Arsenios says that, after the Little Entrance of the clergy with the Gospel, "and after we [the Greek clergy] all went up to the altar / we chanted the troparokontakia [the troparia and the kontakia]" there, both types properly placed in the service in Arsenios's poetic account (Sathas, 1979, 50, vv. 504-05). Arsenios continues, noting that, after a blessing for Patriarch Hieremias and for the Tsar, the Greek patriarchal cantors around the Great Domestikos Paschalis from Constantinople "sang the Trisagios [the Sanctus] in a loud voice" (Sathas, 1979, 50, vv. 510-11). ${ }^{15}$ He then adds, both in his poem and in the briefer account in the memoirs, that everyone sang the Kyrie eleison and the Axios together. The Russian accounts similarly refer to the three-fold performance of the Axios, a procedure drawn for this new ceremony from earlier Russian (and, ultimately, Greek) traditions celebrating the elevation of lower-ranking hierarchs. ${ }^{16}$

13 This summary is drawn from Arsenios's poem and his memoirs; from Nikolaevskii 1879, No. 11-12:566-79; and from Russkaia istoricheskaia biblioteka 1875, No. 103, cols. 314-27 (where the document is incomplete, beginning only with the banquet following the installation ceremony). The descriptions in Nikolaevskii's article use a series of quotations from several contemporary sources; he does not include details about Iov's attendants, including singers, at this point in the proceedings. Many thanks to Drs. Gregory Myers and Miloš Velimirović for their advice on terminology in the following discussion.

14 The Russian sources tend to distinguish between the performance of an "Ispolaeti despota" (usually for the Greek hierarchs or by the Greek singers) and a mnogoletie (generally by the Russian singers for a Russian hierarch), suggesting that the pieces may have been performed in different languages; see, for example, Russkaia istoricheskaia biblioteka 1875, 319 and 323.

15 In both Greek and Russian usage, domestikos (domestichos) or domestik is a lower ecclesiastical official, typically a cantor; our sources here refer to a skilled singer, specifically, the leader of a choir. See, for example, Kriaras 1977, 181-82 and Morosan 1986, 10. Gudziak 1996:233 and 1998, 174, mention the presence of a singer ("pevchii diachok") in the patriarchal suite, and see the documents in Buganov and Lukichev, 1988, 13 and 41.

16 Gudziak 1998, 182-83 and n. 66, calls special attention to the rite of installation itself, which included elements not present in the traditional Greek service-a slap in the face of the visiting hierarchs (which only compounded other indignities they were forced to endure; see especially pp. 186-87). 
According to the Russian sources, the Greek singers performed some final musical elements of the Divine Liturgy: the Cherubic Hymn, the Hymn of Praise ("Dostoino est"), and a second kenanik. ${ }^{17}$ At the special ceremony of enthronement (during which the new Patriarch was seated and then raised from his seat three times by participating clergy, another element taken from earlier rites for the installation of a church hierarch), singers from all three choirs sang the "Ispolaeti despota" together. Here and elsewhere, the Russian accounts specify that the first or great rank (bol'shaia stanitsa) of the patriarchal choir performed. The large Russian choral ensembles were divided into hierarchical ranks or stanitsy, each with several singers, and this ordering was preserved for the new Patriarch's ensemble (comprised, presumably, of the former Metropolitan Iov's singers). Tsar Fedor presented Patriarch Iov with his pectoral cross, mantle, miter, and pastoral staff, and then formally addressed Iov in his elevated rank, and the service concluded with multiple performances of the mnogoletie by the combined choirs. ${ }^{18}$

The same ensembles also performed at the banquets which took place on Sunday, following the ceremony itself, and again on Monday and Tuesday. At this point, although the Greek and the Russian sources describe the same series of events, their chronology is somewhat at odds. All of the Russian accounts place a visit made by the hierarchs to Tsaritsa Irina on Monday; Arsenios, who gives fairly short shrift to events occurring on Monday, in his poem places the visit to Irina on Tuesday, preceded by the same elaborate series of meetings prior to this remarkable honor (the two Patriarchs' meeting is interrupted, they accept an invitation to visit the Tsar, and are then invited by the Tsaritsa). ${ }^{19} \mathrm{Al}$ though Arsenios had been awe-struck at the grandeur of the place settings and the overwhelming bounty of the Sunday banquet, he devotes his greatest poetic energies to his description of this visit to the Tsaritsa. It was, indeed, extraordinary. Like Guy Miege's experiences at court more than half a century later, Arsenios and the Greek clerics were dazzled by the Tsaritsa's chambers, attendants, and jewels, lost in a similar "confusion of glory." Enthralled by the opulent splendor, Arsenios gives a detailed inventory of the pearls, rubies, diamonds, topazes, amethysts, and sapphires which he observed on Irina's headdress alone, and he devotes a full eleven verses to a description of the Persian rugs in her room (which he had occasion to inspect thoroughly and closely as he bowed down to the floor).

17 The kinonik or prichasten (koinönikón in Greek usage) is the Communion hymn. It is not clear, from the citation in Nikolaevskii 1879, 570 (' ... Kheruvimskuiu pesn', da dostoino est', da vtoroi kenanik peli greki"), if the Greek singers repeated the hymn performed by the Russians or if they performed a second, different hymn; see Gardner 1980, 52 and 93-94.

18 Nikolaevskii 1879, 571, summarizing, not quoting from, the Russian sources; in his poem, Arsenios says only that they all sang praises of the three participants (see Pitirim 1968:264, and Sathas 1979, Appendix, 52).

19 Dmitrievskii 1899, 85, gives a more abstract chronology. In his memoirs, Arsenios pinpoints the Sunday banquet on 26 January, but then continues by noting simply that "not too many days later" they were invited by the Tsar to pay a visit and give their blessing to the Tsaritsa. Thyrêt 2001, 85-86, calls attention to Irina's role in the deliberations over the establishment of the Patriarchate, and see also, for example, Makarii 1883-1903, 10:12ff.; as noted above, n. 10, Irina also received an individual letter confirming the results of the 1593 Synodic Act. 
The Russian accounts focus rather on the banquets, which, on Sunday and Tuesday, were interrupted in order to allow Patriarch Iov to make a circuit around the city riding on an ass, a procession accompanied by his singers and which was also drawn from earlier traditions for the elevation of a cleric. Although the Russian scribes detail each location visited by the Patriarchal parade with geographical precision, the processions do not figure in Arsenios's account, probably because he did not participate and would have had no firsthand knowledge of these events; similarly, the Russian scribes probably did not attend the meeting with the Tsaritsa and thus do not include a description of that event, although they mention it briefly. ${ }^{20}$

The banquets rang with the sounds of singing: hymns (various stikhi and slavniki, or hymns of praise) and the mnogoletie in both languages. On one occasion, at the banquet on Monday, the Russian documents outline an extensive musical interlude involving many singers, both Greek and Russian. Patriarch Iov's great stanitsa, headed by singer Ivan Makar'ev, began by performing the slavnik for the Dormition of the Virgin, followed by the second stanitsa of the Patriarch's singers, headed by Pervyi Fedorov, singing a slavnik for the Eve of the Dormition. Next, the Greek singers were requested to perform: "The Patriarchs consulted with one another and had Patriarch Hieremias's singer Dmitrii [Demetrios] and his companions sing in Greek." They then requested that singers associated with the new Metropolitan of Novgorod, Aleksandr, sing, appropriately, a slavnik to the Miracle-Worker Ivan of Novgorod. ${ }^{21}$

The banquets concluded with the traditional and elaborate Muscovite toasts (chashi), each accompanied by a mnogoletie as well as by special hymns. ${ }^{22}$ The toasts also formed a suite of musical performances. The Tuesday banquet, for example, began with the toast to the Virgin and one to Peter the Miracle Worker, followed by a slavnik. A toast was then offered to Tsar Fedor, which included a special hymn and a "great mnogoletie" performed by the sovereign's singers, and the same two types of pieces were performed at the final toast to the Tsaritsa.

Arsenios's account, in combination with the Russian sources, also confirms the frequent interactions among the Russian and Greek singers. The Russians sang in Greek (Pervyi Fedorov and the other members of Iov's second stanitsa sang the "ispolaiti" for Patriarch Hieremias) and then heard the performance

20 Arsenios gives a list of the people allowed to enter the Tsaritsa's chambers (Sathas 1979, Appendix, 61): first the Tsar, then the two patriarchs, then "we" the hierarchs, and then Boris Godunov. No one behind him was permitted entry.

21 Russkaia istoricheskaia biblioteka 1875, 322-23: "A za stolom patriarkhi veleli peti d'iakom pevchim Ievlevym patriarkhovym, bolshei stanitse, Ivanu Makarevu $s$ tovaryshchi, slavnik Uspeniiu prechistye Bogoroditsy osmoglasnik 'Bogonachalnym manoveniem'; i posle togo drugoi stanitse, Pervomu Fedorovu s tovaryshchi, peti veleli Uspeniiu zh liteinoi slavnik chetveroglasnik: 'Priidete prazdnoliubnykh sobor'; i potom posovetovali patriarkhi promezh soboiu da veleli peti d'iakom pevchim Eremeevym patriarkhovym Dmitreiu s tovaryshchi, po grecheski. I posle togo veleli peti novonarechennago Aleksandra, mitropolita Novogorodtskago, d'iakom pevchim slavnik chiudotvortsu Ivanu Novgorodtskomu chetvertago glasa: 'Sviatitelem obraz i vere utverzhenie', i potom poveleli pet' pod"iakom vsem po chinu."

22 General discussions of toasts are in Sokolova 1989; Burilina 1984; and Findeizen 1928, chapter 9 (based primarily on Orlov 1913, which includes a survey of earlier studies of the genre). 
of the Great Domestikos, Paschalis, at the installation ceremony. ${ }^{23}$ The Russian ensembles were also in daily contact with the Greek singers at the more relaxed atmosphere of the banquets. The ceremony also provided an important occasion for singers from outside the capital city, for instance the singers in the Metropolitan of Novgorod's ensemble, to hear the other choirs, including the Greek performers. After about a week in Moscow, the Greek party went to the Trinity-St. Sergius Monastery, where there was a similar musical exchange. ${ }^{24}$

Liturgical singing, of course, was not the only music performed in Muscovy, and another Greek writer, Matthaios Koletzides, provides a glimpse into a very different Russian musical world. Koletzides, like Arsenios, witnessed the crushing events that took place in Russia after Tsar Fedor's death, when the Riurikid line died out and the Tsar's former regent and brother-in-law, Boris Godunov (r. 1598-1605), came to power. A few years into Boris's reign, a claimant to the throne appeared, the so-called False Dmitrii, who, after having secured military and financial aid from Polish political and ecclesiastical authorities, began his march to Moscow in the fall of 1604 , when he crossed into Russian territory as the miraculously-living youngest son of Ivan the Terrible. Dmitrii made his way north and east to Moscow through a combination of military maneuvers and personal charisma, and when Tsar Boris died suddenly in April 1605, the road was clear. Dmitrii made his grand entrance into Moscow in June and he was crowned a month later, on 21 July.

The new Tsar immediately set about getting his intended Polish bride and Tsaritsa, Marina Mniszech, from Poland to Moscow, and he dispatched an envoy to Cracow to make the arrangements. A proxy marriage took place in November 1605, and Marina set out for Muscovy the following spring. It was a long and difficult journey lasting almost two months, in a procession made up of several thousand attendants. The unwieldy parade crossed the border at Smolensk, which is where Koletzides observed it.

Most of the available information about Matthaios Koletzides is gleaned from his poem. ${ }^{25}$ In it, he identifies himself by the adjective "polítes," suggesting that Constantinople (known otherwise as "hè Pólē," that is, "the City") was his place of origin. Koletzides's ecclesiastical rank at the time of writing (1606) is that of hieromonk, but he informs the reader that he was formerly an archimandrite on the small island of Proikonesos (Marmaras) in the Sea of Marmara (Propontis), which lies between the Aegean and the Black Seas (Knös 1962:231, vv. 26-27). A special section of the poem's introduction (vv. 43-74)-and the entire poem,

23 Russkaia istoricheskaia biblioteka 1875, 319: "I posle soversheniia zdraviia uchali drugaia stanitsa, Pervoi Fedorov $s$ tovaryshchi, peti sviateishemu Ieremeiu, patriarchu vselenskomu, $s$ ispolat iu."

24 Documents recording the brief trip to the Trinity-St. Sergius Monastery are in Buganov and Lukichev 1988, 40-41, which lists the liturgical singing at the monastery and gifts given to the Greek party, including the singer.

25 His poem is published in Knös 1962, with a brief summary in Papoulidis 1974:293-94. The spelling of Matthaios's family name is varied; we have used the spelling he himself gives in his poem (in Greek): "Kolētzídēs" (Knös 1962:231, vv. 25 and 28; 252, v. 745). Other sources use variant forms; see, for example, "Kolitzidis" (Knös 1962:229, in French) and "Kolidzidis" (Alexandropoulou 1989-90:61 et passim, in English). In Greek-language works, his name is listed as "Kolytzëdēs" (Sathas 1868, 403) and even as "Polytzēdēs" (Legrand 1963b, 1:28). 
for that matter-is dedicated to Gavriel Severos, former Metropolitan of Philadelpheia and exarch of the Patriarchate of Constantinople in Venice. Severos was an eminent theologian and hierarch who spent most of his life in Venice and contributed greatly to the development of the Greek Orthodox community there. The fact that, in 1612, Koletzides's poem was printed in Venice by Antonio Pinelli, might thus be a result of his acquaintance with Severos; after all, already in 1603 Koletzides had edited and corrected a Venice edition of the extremely popular Thesauros, which contained the homilies of Metropolitan Damaskenos Stoudites, one of the most prestigious and erudite clerics of the sixteenth century and a hierarch whom Matthaios Koletzides may have known in his youth. ${ }^{26}$ These two publications attest to the fact that Matthaios Koletzides must have indeed been a learned and devoted champion of the Eastern Church, who saw as his mission to defend Orthodoxy against its enemies, primarily the Jesuits, the "pseudoprophets" of his time, as he calls them (Knös 1962:231, v. 14). We have no specific information regarding his presence in Smolensk or his whereabouts before and after the events described in his poetic account. He does tell us in his poem that in the two-year period from 1604-06, he was incarcerated in the Spas (Spaskii, Savior) Monastery (Knös 1962:231, v. 22, and 252 , vv. 747-48). Finally, Koletzides himself dates the composition of his poem in early June 1606 (vv. 741-44). ${ }^{27}$

In his narrative poem, Koletzides describes the impressive entrance of Marina's large Polish entourage as they crossed the border into Muscovy in early April 1606: ${ }^{28}$

The cavalrymen arrived, the infantrymen came and the band began to strike up and drums began to roll.

The queen arrived in great magnificence, she passed right through the ranks of the foot soldiers; the horns began to sound and the drums began to beat,

There came the noblemen out to meet her, they bowed from afar, as befitted her honor; out of the monasteries came the elders

26 The autograph manuscripts of the 1603 and 1612 editions are in Rome: the former in the Casanatense library (B.VII.85) and the latter in the Angelica library (OO.4.76) (see Legrand 1963, 1:28 and 90-91). It is worth mentioning that Damaskenos Stoudites and the later Metropolitan Hierotheos were most likely fellow-students in Constantinople, having studied under the same teacher there; Stoudites, moreover, is known to have taught both Patriarch Hieremias and Archbishop Arsenios (see the chronicle of Pseudo-Dorotheos [Hierotheos] in Sathas 1979, Appendix, 6 and 9; and Demetrakopoulos 1984, 42-46.

27 Koletzides says that he wrote the poem during the week of the Pentecost, which in 1606 fell between June 2 and 8 .

28 Knös 1962:244-45: "Ephthásan hoi kaballaroí, êlthan hoi tarampánoi / kà árchepsan tà órgana kaì paîksan hoi tympánoi. // ... // Éphthase hē basílissa mè phantasía megálē, / apò tēn mésē pérase poú 'tan hoi tarampánoi. / edōkasi tà boúkina kaì paîzan hoi tympánoi, // ... // Eksébēkan hoi árchontes eis synapántēsín tēs, / apò makrà proskýnēsan hōs êton hē timē tēs. / eksébēkan hoi proestol apò tà monastêria / kaì tēn eprö̈pántēsan mè tà thymiatēria. / Estáthēsan tà órgana kaì holes hoi pantiéres / kaì stékountai kaì akarteroûn nà pâsin hoi patéres." 
and greeted her with the censers.

The band and all the banners came to a standstill and stop and wait for the fathers to arrive.

The entrance Koletzides describes was obviously calibrated for maximal impact, as the Polish party made its first foray into Muscovite territory. Such militarystyle fanfares were common in Russia; indeed, they were repeated with even greater ceremony when Marina's party finally reached Moscow. Arsenios describes the party's entrance into the capital, which had been planned meticulously by the prospective bridegroom and which featured Russian musicians as well as Polish, including "many sonorous instruments: trumpets, cymbals, drums, and horns, and various others all sounding loudly, marching on the way."29 Back at their Russian debut in Smolensk, however, some of Marina's musicians may have provoked an early misunderstanding between the Poles and the Russians, a potent harbinger of the far more serious misunderstandings to come. An account written by one of Marina's anonymous attendants describes the Russians' amazement at hearing music at a mass celebrated by the Polish entourage just after crossing the border at Smolensk: "The music during the mass really surprised the Russian folks and, crowding around, they even broke down the barrier." 30

The Polish writer gives no further details, but the context-musical performances as part of a liturgical service-obviously provoked a reaction that Koletzides's brassy parade fanfare did not. What kind of music might have created such a riot? Although polyphonic music would certainly have been familiar in the context of an Orthodox liturgical service at this date, especially in a border town such as Smolensk, the Russians may simply have been surprised by the Polish choir's unfamiliar style of singing. It seems more likely, however, that they were reacting to something far less familiar and far more disruptive: the presence of musical instruments as part of a liturgical service, a practice excluded from seventeenth-century (as well as twenty-first-century) Russian Orthodox practice. In addition to the fanfare instruments Koletzides describes at the entry procession, we know from other sources that the Polish suite included an organist, Pan Gabriel, who came with his own assistants. ${ }^{31}$

29 Dmitrievskii 1899, 108: “órgana pollà eúēcha. sálpingai, kýmbala, týmpana kai boúkina kaì álla tinà mousikà pánta alalázonta, kath' hodòn poreuómenoi." Western observers described the same type of fanfare music, for example Konrad Bussow, who mentions shawms and kettledrums in the same entry procession; see, for example, Bussov 1961, 235: "20 Mann mit Schollmeyen und Kesselpauken" (and see also p. 242). Bussow's work is translated in Bussow 1994, where this passage appears on p. 50 (where it is translated as "trumpets and kettledrums" rather than as "shawms and kettledrums").

30 'Muzyke vo vremia messy 'moskva' ochen' udivlialas' i dazhe, tolpias', lomala ograzhdenie" (Bulanin 1995, 37). It is not clear what kind of barrier or railing the author had in mind. In the closely related account by Martyn Stadnicki, the Russians are reported to have broken the benches ("lomali dazhe skam'i"; 1906:146). This account does not mention the celebration of a mass, but it is clearly labeled as taking place on a Sunday. Both sources were available for this study in Russian translation only. Another Polish observer, Stanisław Niemojewski (ca. 1560-1620), a merchant in Marina's retinue, mentions the celebration of a mass on this date, but does not refer to the musical incident (Hirschberg 1899, 8, and, in Russian translation, Titov 1907:24-25).

31 Pan Gabriel and his crew were among those killed in the 1606 uprising, and their names are listed among the dead. The Polish diplomats Oleśnicki and Gosiewski listed thirteen people associated 
Certainly some Russians knew that instrumental music played a role in other religious traditions. Just a few years before Marina made her trek to Moscow, for example, Tsar Boris's envoy to London, Grigorii Ivanovich Mikulin, attended church services with Queen Elizabeth in January 1601 and reported back about the music he had heard. The context was unfamiliar and Mikulin apparently asked his hosts for clarification about the proceedings, but his report described the service without comment (although he does emphasize that the instruments were actually played in the church itself): "And when the queen entered the church, at that time they began to play organs and horns in the church, and on many other instruments and to sing, and the officers said that they were singing the psalms of David."32 So why should there have been such a strong reaction to the music at Marina's mass, whatever it may have been, if so many of the elements were familiar, even if they were outside accepted Orthodox practice?

The accounts of the events in Smolensk as described in Koletzides's poem and in the anonymous Polish narrative highlight a distinction crucial in Muscovite music. Koletzides tells of an acceptable use of military-style fanfare music, brilliantly executed by Marina's retinue, but not unfamiliar, and greeted with apparent equanimity by the Russian spectators. The anonymous Polish account, on the other hand, describes an unacceptable context for an unfamiliar kind of music (most likely including instrumental performance) which was received, predictably, with horror. Mikulin's experience with musical instruments used in the context of religious services was not widely shared, nor would his account have circulated outside the topmost ranks of the Kremlin; these and other diplomatic reports could not prepare ordinary observers for the sight and sound of Western-style music, performed as part of a religious service and right in public, barriers or no. As an indication of the depth of feeling religious music engendered among Orthodox Russians, one needs only to recall the anguished cri de cœur sounded a few years later by Patriarch Germogen, in the context of the next phase of the Troubles, when the Poles were occupying Moscow: "The Latin singing in Moscow," the Patriarch declared, "I can bear to hear no longer."33

Even much later and in the capital city of Moscow, the use of instruments in connection with a liturgical service created a similar, horrified reaction. Bernard Tanner, part of the Polish embassy of 1678, described (with a tone of con-

with Gabriel (Ustrialov 1834, 191). Niemojewski mentioned two servants associated with the organist (Hirschberg 1899, 94, and Titov 1907:97).

32 Mikulin's report is published in Bestuzhev-Riumin 1883, 335 ("v vargany i v truby, i v-ynye vomnogie igry, i peti"). Mikulin heard a great deal of music in England, and many extracts from his account are translated in Hotson 1954.

33 Quoted in Gardner 1978, 1:551, and also (in a slightly different translation) in Morosan 1979, 159. (There is a somewhat different reading of this passage in the chronicle source reprinted in Liberman, Morosov, and Shokarev 1998, 354.) Germogen (or Hermogen), the Metropolitan of Kazan, was appointed Patriarch by Vasilii Shuiskii in 1606, replacing the Patriarch Dmitrii had installed the previous year. He subsequently served as a unifying figure in the last years of the Troubles; see Platonov 1970, 143ff., and the brief overview in "Hermogen" 1979. Later in the century, Protopop Avvakum expressed similar sentiments regarding Western-style singing: "In Moscow in many holy churches they sing songs, not divine singing, [but] in Latin, their rules and practices are Latin, they wave their arms and nod their heads and stamp their feet as is the custom among the Latins to the sound of the organ" (quoted in Metallov 1915, 82). 
descension familiar in foreign descriptions of Orthodox traditions) the Russian response to the Poles' Easter celebrations: ${ }^{34}$

We [in the Polish party] celebrated Easter in our own fashion, solemnly with trumpets and drums. Our pleasant music and our singing to [notated] music, which so caressed the ear, was extremely unusual to our uneducated listeners. They all stood, mouths agape, in amazement that we could pray to God to the accompaniment of such pleasant singing and playing of instruments; it seemed to them that this rather inclined one's soul to dancing.

For the Russians, music, particularly instrumental music, thus provided a potent shorthand for both foreign culture and secular decadence. ${ }^{35}$

Arsenios's account of Marina's wedding to Dmitrii helps us understand that the impact of such foreign sounds would only have been heightened by the realization that this alien music was being performed for the woman who was to be the new Tsaritsa, a woman whose Orthodoxy was, and would continue to be, seriously and legitimately questioned. Arsenios was present at the wedding in Moscow on Thursday 8/18 May and at some of the festivities following, and his account gives us a more informed view than that of many of the Polish visitors. One of the Polish observers, Stanisław Niemojewski, was simply baffled by the ceremony and described the scene dismissively and incuriously: “... a few clerics sang something from books, but it was impossible to understand anything except 'Gospodi pomilui' [Lord, have mercy], because they repeated that more than a hundred times." ${ }^{36}$ Arsenios, however, describes the wedding service in more detail, dwelling on the imposing staging of the ritual and the setting of the church, lavishly decorated with rich brocades and three specially prepared silver-gold stools with precious pillows, but noting also that the singers performed the mnogoletie several times, and also sang the Axios (Dmitrievskii 1899, 110-11).

Arsenios also foreshadows the terrible events to come, noting with horror that neither Dmitrii nor Marina took communion at the combined coronationwedding ceremony, which was designed deliberately in order to confuse the

34 Tanner 1689, 32-33: "Nobis ritu patrio solenniter cum tubis \& tympanis Pascha celebratum est: ubi insolitum maxime visum incultis spectatoribus, quod e chartis signis musicalibus notatis, tam dulces moduli, \& gratissimi auribus vocum concentus elicerentut: quo factum, ut adstarent apertis buccis attoniti omnes, quomodo preces in Deum dici possint a nobis eo tempore, quo tam jucunda auribus seu voce, seu instrumentis musicalibus canerentur, quae ipsis magis ad saltandum videbantur animum excitare." Many thanks to Dr. Robert Fradkin for his advice on the Latin text. A Russian translation is in Ivakin $1891,33$.

35 As Vladimir Morosan has demonstrated, even the word "music," musikiia, in Russian usage of the sixteenth and seventeenth centuries had a special and specific meaning: penie (singing) was what happened in church, whereas musikiia implied instrumental (and therefore non-Orthodox) entertainment (Morosan 1979:esp. 152). Findeizen 1928, 184, presents a series of definitions of musikiia from sixteenth- and seventeenth-century Muscovite glossaries, all of which refer, often in a highly negative manner, to instruments or to playing. Definitions from earlier periods are in Sreznevskii 1958, 2:col. 196. One might also note, however, that there is evidence of some musical interchanges among the various religious groups in Smolensk, at least later in the century (Kotliarchuk 2001, 88-90), and there was a military-style fanfare in honor of an entering bishop in Smolensk in 1637 (Krajcar 1967:425).

36 Hirschberg 1899, 49 ("Śpiewało też przedtym kilka popów coś z ksiąg, ale nie rozumieć im było nic, prócz: 'Hospody pomiłuj;' więcej niż ze sto razy powtarzając") and Titov 1907:59. 
issue of Marina's purported conversion to Orthodoxy; as Arsenios writes, this was "the first and great cause of sorrow and the origin of the scandal and the cause of many evils for all the people of Muscovy and all of Russia." ${ }^{37}$ The Polish accounts linger over descriptions of the public, mixed dancing and of Dmitrii's stunning Hussar outfits at the celebrations following the wedding, whereas Arsenios dwells upon the dangers of such seemingly innocuous trappings as clothing, noting with concern, for example, that on Sunday, 11/21 May, when the Patriarch and many high-ranking clergy brought gifts to the newlyweds, Marina was wearing Polish dress. (The anonymous Polish account notes that at a gathering apparently held later that day, both Marina and Dmitrii wore Polish clothing.) This was not trivial, as Arsenios realized, for he continues by observing that this sort of breach of etiquette and tradition contributed to the subsequent riots "that were responsible for the deaths of the Tsar and of many Russians and Poles in Moscow." 38 Arsenios highlights Marina's fateful historical role through the use of an imaginative simile, portraying her as a modern-day Helen of Troy-indeed, he takes this comparison several steps further, by including in it every player in the drama surrounding Marina. Thus, just as Helen was responsible for the destruction of Troy and the loss of so many men (Arsenios's list includes Achilles, Hector, Ajax, and Patroclus), so Marina was liable for setting Moscow on fire and sending to their death or into exile two Tsars (Dmitrii and a purported second lost son of Tsar Ivan, named Peter, who was hanged), along with her family and scores of Russians, Poles, and Germans (Dmitrievskii 1899,114 and 139-41).

Arsenios survived the chaos of the Time of Troubles in the capital city, focusing in his memoirs on the tumultuous political events of this period. $\mathrm{He}$ finally brings us full circle, describing briefly the entrance into Moscow of young Mikhail Romanov, whose election to the throne marked the end of the Troubles. ${ }^{39}$ Even his brief account is valuable, for information on Mikhail's entry

37 Dmitrievskii 1899,112 . For a discussion of the deliberately dual interpretation of this double ceremony, see Uspenskii 1997 and Barbour 1966, 255-56.

38 Dmitrievskii 1899, 113, where he also describes the Patriarch's visit to the newlyweds. The festivities apparently held later that day are described in Bulanin 1995, 54, and in Stadnicki 1906:160; both sources note that on the previous day, Saturday, 10/20 May, there were "no elaborate dishes, no ceremony, and no music," but various Polish military figures were invited to the meal, for which Marina wore Polish dress and Dmitrii appeared in Muscovite clothing. Some well-informed Western writers were also able to spot some of these warning signs; see Bussow 1994, 61, who observes that Dmitrii "no longer went to church as diligently as before, he lived by adhering in all things to foreign ceremonies and customs, ate unclean food [veal], went to church without cleansing himself [and] did not revere the icon of St. Nicholas ..."

39 The issues surrounding the authorship of these last passages in Arsenios's memoirs are complex. Two hierarchs accompanying Patriarch Theophanes of Jerusalem played a role in the compilation of Arsenios's work: archimandrite Christophoros and archdeacon Neophytos. According to Demetrakopoulos 1984, 26-27 (summarizing Dmitrievskii 1899, 191-93), Christophoros "copied [the portion of] Arsenios's memoirs that reached up to 1611 , recorded their continuation up to 1613 , and composed Arsenios's biography up to 1619. Archdeacon Neophytos copied the memoirs in 1634, when he found himself in Moscow once again, and added the epigrams, noting that Arsenios received the copy in 1619; then, with the help of Arsenios's acolyte, monk Kyrillos, he completed Arsenios's biography-synaxary. At the end of his own manuscript (later [the lost] Soumela 85), Neophytos also copied archimandrite Christophoros's bibliographical note, adding however his own name." Thus, although Arsenios was apparently 
procession is scarce. Arsenios describes multitudes of ecclesiastical figures joining with the populace, carrying the cross, icons, torches, and censers. Everyone together-"men and women, boyars and subjects, young and elderly, children and adults, boys and girls"-met Mikhail's party with singing ("Glory to God in the highest" and "Let the heavens rejoice and the earth be glad"), which lasted for two miles along the route; finally, after more chanting and a long prayer just outside of Moscow, the whole massive party made its way into the city to the Cathedral of the Immaculate Mother of God "with great singing." ${ }^{40}$ The singing ensembles, so well developed at the installation ceremony of 1589 , had suffered decline and neglect during the political upheavals, and appear to have fully recovered only over the course of the 1620 s and 30s. Arsenios's brief account suggests that, for Mikhail's entrance at least, the joyous populace of Moscow itself may have helped to remedy this loss. ${ }^{41}$

However, Arsenios also tells us, somewhat ambiguously, that among the procession were "musicians" (mousikoi). He describes these musicians as placed between the ranks of the clergy and the remainder of "the Lord's entire Christian populace of Muscovy." Arsenios is consistent in his terminology throughout the memoirs, using the Greek term for "chanting" to indicate liturgical singing, which he contrasts to the "musicians" of Mikhail's and also Marina's entry into the capital. It seems reasonable to conclude that Mikhail was accompanied by an instrumental flourish, a practice known in later Muscovite royal processions as well, sometimes in conjunction with religious singing. ${ }^{42}$

Finally, this cluster of Greek sources tells us something about another pivotal event, the installation of Tsar Mikhail's father, Filaret, as Patriarch of the Russian Church in 1619. This was an extremely important occurrence in the history of the

involved in or supervised the production of his memoirs in 1619, he may not have directly composed the post-1611 portion of the text. Demetrakopoulos 1984, 112 and 151-52 (after Dmitrievskii 1899, 191-93 and 182-83), concludes that Arsenios probably narrated the events between 1611 and 1613 in free form to Christophoros, who "composed [the text] at [Arsenios's] dictation and perhaps with the help of Arsenios's notes" in 1619.

40 Dmitrievskii 1899, 175: "ántres te kai gynaîkes, árchontes kaì archómenoi, néoi te kaì gérontes, mikroí te kà̀ megáloi, neanískoi te kaì parthénoi"; "Dóxa en hypsístois Theôi, kaì epì gês eirēnē en anthrōpois eudokía"; and "Euphrainésthōsan hoi ouranoí, kaì agalliásthō hẽ gê."

41 Zvereva 1989 traces fluctuations in the choirs before and after the Troubles. Judging from the Russian sources documenting Mikhail's coronation and Filaret's installation, there does appear to have been less elaborate singing for these ceremonies than there had been at the 1589 celebrations marking the establishment of the Russian patriarchate. This latter event, however, was of particular importance and so perhaps is not the best benchmark. Mikhail's coronation is described in Sobranie gosudarstvennykh gramot 1822, 3:70-87, with references to two groups of singers, on the right and left kliros (80), and to unspecified "diaki" who sing the mnogoletie (73). This is similar to the descriptions in Russian accounts of Filaret's installation ceremony.

42 Arsenios uses "psállein" (chanting) and its derivatives to describe liturgical singing in Dmitrievskii 1899, 54, 81, 84, 105, 110-11, 175-77, and 195; he mentions the musical instruments ("mousikà organa") at Marina's entry procession on p. 108, and in his description of the musicians ("mousikor") at Mikhail's procession on p. 175. Royal processions also used instrumental fanfares later in the century. When Tsar Aleksei returned to Moscow from his military campaign in 1655, the entry procession included trumpets, percussion, and the shawm-like surny as well as a contingent of clergy, including boys in white clothing who sang from papers they held in their hands (Sobranie gosudarstvennykh gramot 1822, 3:539-40). Adolf Lyseck (1828:316), documenting the Imperial embassy to Moscow in 1675, described the Tsar's departure to the Trinity-St. Sergius Monastery accompanied by trumpets and drums. 
Russian church, for not only did it signify an unprecedentedly close relationship between Tsar (the inexperienced sixteen-year-old son) and Patriarch (the worldly and politically astute father), but it also served to heal a final wound inflicted by the long upheavals, for the Patriarchal seat had been vacant since 1612. Filaret had taken an active role in the negotiations with Poland during the Troubles and had been incarcerated there for several years; his ascent to the Patriarchal throne thus marked equally his safe return from captivity and was cause for great celebration. The event, like others surrounding the Time of Troubles, quickly passed into broad popular consciousness. A song on Filaret's return, from the very year of his reappearance in Moscow, was preserved in the collection of texts compiled in the far Russian North for the English visitor Richard James. ${ }^{43}$

At the time of Filaret's return, Theophanes, Patriarch of Jerusalem, was already in Moscow for the familiar purpose of collecting alms. ${ }^{44}$ Even before Filaret arrived, the Patriarchal party had been treated to lavish banquets at court and elaborate processions by multitudes of clergy, with singing accompanying the full panoply of such events: parades of censers, crosses, icons, and the like. Arsenios continued to play an active part during these ceremonies in his role as a liaison between the Russian and Greek Orthodox communities-a necessary task. During their stay in Russia, for example, Theophanes's party celebrated Divine Liturgy along with some Russian clerics, including singers associated with the Metropolitan of Kazan. The visiting party sang in Greek and followed what were, to the Russian observers, unfamiliar and disturbing liturgical practices. The Russian hosts summoned Arsenios, who was able to provide appropriate translation and guidance for the visitors. ${ }^{45}$

At the ceremonies marking Filaret's installation, Russian sources mention several performances of the mnogoletie, alternating between singers of the right and left kliros, as was traditional; they do not indicate specifically that Patriarch Theophanes's singers performed. ${ }^{46} \mathrm{~A}$ later account, describing Theophanes's re-

43 The song texts in the James collection have been published widely. An English translation of the song celebrating Filaret's return, which mentions singing in the context of a religious service, is in Zenkovsky 1974, 505. An overview of Filaret's career, in English, is in Keep 1959-60.

44 An anonymous account of Theophanes's trip to Moscow and his sojourn there (probably written by the same Jerusalemite Archimandrite Christophoros who copied and completed Arsenios's memoir) contains information regarding musical practices and partly describes the musical events that took place at some of the important ceremonies in which Theophanes and the clerics escorting him participated; see Papadopoulos-Kerameus 1963, 1:250-63.

45 The description of the unfamiliar practices at the liturgy celebrated by the visiting Patriarch Theophanes and his suite is in Leonid 1883, 165-67, and is discussed in Kapterev 1895, 31ff. This undated account may describe events that took place before Filaret's return to the capital, for he is not mentioned as participating. These events may also have occurred slightly later, for there were, apparently, banquets held after Filaret's return which he did not attend (for example, Dvortsovye razriady 1850, 400). On Arsenios and his self-appointed task as liaison between the Orthodox worlds, see Fonkich 1977, 58, and also Demetrakopoulos 1984, especially 91-116.

46 Kliros can refer both to the raised platforms to the left and to the right of the iconostasis as well as to the singing ensembles who occupy those spaces. Patriarch Filaret's installation is described in Sobranie gosudarstvennykh gramot 1822, 3:187-201, and in Dvortsovye razriady 1850, 400-07. There is some confusion over the date of Filaret's installation ceremony. A contemporary Greek source puts the date of his designation as Patriarch (narechenie, in Russian usage) as 18 June, with the installation ceremony itself (postavlenie) on Sunday 20 June (see the anonymous account of Patriarch Theophanes's 
turn trip through Kiev, does mention by name one of the Patriarch's singers, the monk Gavriel, who participated in the consecration of several Ukrainian hierarchs. Gavriel would certainly have been in the patriarchal party in Moscow as well, and must have participated in the important events marking Filaret's installation. ${ }^{47}$

At the end of his stay in Kiev, Theophanes issued an edict that appears to summarize his experiences in both Muscovy and Ukraine, and his observations include a tantalizing hint of musical performances clearly far beyond the bounds of accepted Orthodox practice. Theophanes's stay in Moscow was marked by several occasions during which Muscovite observers noted with dismay divergences in liturgical practice; such divergences, indeed, led to some of the modest theological investigations and emendations directed by Filaret early in his term. ${ }^{48}$ In his statement issued in Kiev, probably in early 1621, Theophanes, in his turn, lays out several specific objections to practices he had observed, including one relating to memorial services. He had taken note of the presence of music and food at gravesite services for the dead; such services, he says, should involve only prayers in church and alms. ${ }^{49}$ Theophanes's observation strongly implies not liturgical singing, but the use of musical instruments, hinting at ancient folk traditions long associated with funeral ceremonies. The Patriarch's remark takes us far beyond the constraints of this article, but one might note that the instrumental practice to which he alludes involved a completely different subset of musical instruments, quite distinct from the fanfare types used to herald Marina's arrival in Smolensk. Throughout the first half of the seventeenth century, Russian officials issued a stream of documents condemning such instrumental practice, which was usually associated with the skomorokhi, jongleur-type entertainers widely censured for their shameful (and ubiquitous) behavior, especially in connection with important holidays and events. Theophanes's comment suggests that he had witnessed some of these ancient traditions that had seeped into ordinary religious practice. ${ }^{50}$

trip to Moscow in Papadopoulos-Kerameus 1963, 258-62). Russian sources consistently give 22 June as the naming ceremony, and 24 June (Thursday, on the Feast of St. John the Forerunner) as the installation (see, for example, Sobranie gosudarstvennykh gramot listed above and Dopolneniia $k$ Aktam istoricheskim $1846,209-21)$. One Russian historian, P. Kazanskii $(1848,17)$, bridges the gap, noting that Filaret was "narechen" on 18 June and was "khirotopisan" (sworn in) on 24 June; he gives no sources.

47 See Yurchyshyn-Smith 2004:98, citing Papadopoulos 1907, 60. See also the discussion in Makarii 1883-1903, 11:249-50.

48 See n. 45 above, as well as the discussion in Kazanskii 1848:1-26; Makarii 1883-1903, 11:ff; and, briefly, Yurchyshyn-Smith 2004:95.

49 Makarii 1883-1903, 11:264 (and Yurchyshyn-Smith 2004:98), citing Arkhiv iugo-zapadnoi Rossii 1872, 5:chast' 1, No. 1 (p. 8). Makarii paraphrases the gravesite practice as taking place "s muzykoiu," that is, implying instrumental music rather than liturgical singing (penie); Papadopoulos 1907, 65 (probably using Makarii as his source) refers unambiguously to "mousikà órgana." Makarii 1883-1903, 11:264, n. 208 notes that the document (gramota) is dated 1620, but includes the names of the hierarchs Theophanes had consecrated in January 1621 . Theophanes also commented on wedding practice, observing that at weddings there was some sort of drink served at the singing of the kanonik ("Accept the body of Christ" ["telo Khristovo priimite"]). Earlier, Patriarch Hieremias had noted food-related transgressions in Ruthenian practice; see Gudziak 1998, 204.

50 There is substantial literature on skomorokh musical practices in this period; see, for example, Findeizen 1928; Belkin 1975; Likhachev, Panchenko, and Ponyrko 1984; and Koshelev 1994, and the 
This constellation of Greek accounts from the decades around 1600 thus provides us with a rich image of Muscovite music-making, both sacred and secular, adding substance and real-life experience to the meticulous documentary studies of the Russian singing ensembles. But what was the legacy of such interaction? The turmoils of the Time of Troubles and its aftermath reduced the ranks of the pevchie d'iaki in sheer numbers (and, consequently, in the delicate hand-off from teacher to student), and it took some time for the ensembles to build themselves back up. Nevertheless, visiting ensembles continued to expose Russian singers to different traditions of Orthodox liturgical music. In the middle of the century, another visiting Orthodox cleric provides us with evidence of other places in which such interaction might have been maintained or revived, suggesting a lively musical development in perhaps unexpected arenas.

Paul of Aleppo was an archdeacon who accompanied the Patriarch of Antioch, Makarios, on a trip to Moscow in the mid-1650s and again for the Church Council called in 1666-67. His observations were sharp and wide-ranging and, like many foreigners, he came away from his experience in Moscow with a kind of exasperated appreciation for the extreme piety and the equally extreme rigor of the Muscovite religious praxis. ${ }^{51}$ In several instances, Paul's narrative provides glimpses into the differences between the liturgical practices of the Ukrainian lands through which the visitors traveled and those of their destination, in Muscovy itself.

It was a propitious time for Paul to jot down his observations, for the recently installed Russian Patriarch, Nikon, was in the midst of far-reaching reforms in all areas of church practice, including singing. ${ }^{52} \mathrm{He}$ had turned for expertise to the learned clerics of Ukraine and Belorussia, who, along with their expert singers, came to Moscow in great numbers from the middle of the seventeenth century on. The new Ukrainian singers, particularly at first, were distinguished by title in the Russian documents, where they are called not pevchie, but rather vspevaki (both terms are translated as "singers"). Both groups performed liturgical music for the Tsar himself, although a 1657 document indicates that they appeared separately, the vspevaki in this case singing at the All-Night Vigil and the gosudarevy pevchie d'iaki at Divine Liturgy. Later on, Ukrainian singers appear to have been integrated into the rolls of the sovereign singers and the other ensembles, generally without distinguishing labels. ${ }^{53}$ Nikon also turned to experts from farther afield, inviting a Greek

extensive bibliographies in all of these sources. See also the indictments of skomorokhi and their musical entertainments in the Domostroi (Kolesov and Rozhdestvenskaia 2000).

51 We have used three translations of Paul's work for the present article, listed by translator: Balfour 1829-36; Murkos 1897-98; and Radu 1949 (which covers Paul's trip only through Ukraine). On Paul's account, and for additional bibliography and biographical information, see Halperin 1997 and 1998-99.

52 The voluminous literature on Patriarch Nikon is summarized, most recently, in Bubnov 1993 and Bulanin 2004b.

53 The 1657 document is in Zabelin 1872, pt. 1:289. None of the singers from the 1650 s listed in Kharlampovich 1968, 72-74 and 317-23, appears in Parfent'ev 1991, which includes singers in the established choirs in Moscow; later singers (from the 1680s-90s) identified as Ukrainian in Kharlampovich 1968, 324-28, do appear in Parfent'ev's listings; occasionally a singer is also labeled as a "vspevak." 
singer, hieromonk Meletios (Meletii, in the Russian documents), to come to Moscow, where he worked for several years as a teacher and a copyist. ${ }^{54}$ Patriarch Nikon himself had a special interest in music, dating from his time as Metropolitan of Novgorod, when he adopted the practice of including Greek and Kievan singing. The Metropolitan, explains his seventeenth-century biographer, "assembled klirosy of wondrous singers and exceptional voices [who produced] animate singing far better than an inanimate organ; and no one else had such singing as Metropolitan Nikon." He continued to support such diversity as Patriarch, making an effort to gather together a variety of people at his New Jerusalem Monastery, including Greeks, Poles, Belorussians, and "Cherkasy" (Ukrainians). ${ }^{55}$

Paul's work indicates how this burgeoning interest and reliance on Ukrainian singers may also be linked to familiarity with Greek singing styles. In his account, Paul mentions several occasions during his transit through Ukraine at which he heard readings or singing in Greek. Paul himself participated in one of these services, noting that "[a]t the time of the Epistles [on the Eve of the Feast of the Holy Apostles], one of the Deacons stepped forth to read the Epistle of the day; and I recited the Gospel for the Apostles in Arabic; and, according to their custom here, that for Our Lady, in Greek." He repeats the observation that chanting in Greek was customary in Ukrainian practice in another passage, where he explains that Patriarch Makarios "blessed his assistants and they chanted to him in Greek 'Many years,' for in the large convents they have preserved the custom of singing it in Greek." 56

Although Paul also refers to the singing of an "Armenian melody" and to singing "in an Eastern style" in Ukraine, his descriptions do not tell us with any certainty that the music being performed was actually Greek (or Armenian or Eastern) in origin. ${ }^{57}$ Nevertheless, his observations do confirm that liturgical singing in Greek was part of the tradition of Ukrainian practice at the very time when Ukrainian scholars and singers were being imported to Moscow for their intellectual and musical expertise. Is such singing related to the chant dialect called grecheskii rospev [Greek chant], which appeared in Muscovite sources in substantial numbers in the second half of the seven-

54 Meletii's career in Moscow is outlined in Bulanin 2004a, and see also the surveys in Igoshev 1992:147; Protopopov 1976:123-24; and Parfent'ev 1991, 85-86. Meletii was heavily involved in Nikon's later trials, acting as a messenger; see Makarii 1883-1903, 12:438ff, and Papadopoulos 1907, 125ff.

55 Translation from Morosan 1986, 42. Nikon's biography was written in the 1680 s by I. K. Shusherin (1871; see p. 42 on the many foreigners at the monastery, and p. 13 and note on his music as Metropolitan). See also Leonid 1874, 13. Findeizen 1928, 1:267-68, cites other records of Greek singing in the presence of visiting patriarchs, mentioning singing by the Greek archimandrite Dionisios in addition to Meletios.

56 The first passage is quoted from Balfour 1829-36, 1:219; see also Murkos 1897 no. 4:62, and Radu 1949:703. The second quotation is in Radu 1949:676: "Le patriarche benit les assistants et on lui chanta en grec: 'Pour beaucoup d'années, Seigneur', car dans les grands couvents on a conservé l'usage de le chanter en grec."

57 "Puis, les deux chœurs chantèrent: 'Gloire à Dieu, dans les cieux', d’après une mélodie arménienne, d'une voix agréable, aves les chantres qui sont à la tribune de lorgue, c'est-à-dire les jeunes enfants, dont la voix se déployait avec toute sa force. ... A la fin de la messe de ce jour, chantée d’après la musique orientale, nous sortîmes de l'église au matin"; in Radu 1949:702; see also Murkos 1897 no. 4:61. 
teenth century? There are many theories as to the nature of this Muscovite Greek chant, debating its origins as either actual, authentic Greek chant or as "Greek" chant derived in fact from Ukrainian practice. Several scholars point to the presence of Meletios/Meletii in the second half of the 1650s and into the early 1660s, and to the singers associated with the Patriarch of Antioch's suite as being influential in spreading Greek, or "Greek," singing styles. ${ }^{58}$ Paul's observations (including his participation in liturgical services), combined with the evidence from Arsenios's earlier account, introduce alternative or additional routes by which traditions of singing in Greek, unfiltered by Ukrainian practice, might have made their way to Moscow. Although the kind of active exchange among Greek and Russian singers Arsenios describes (especially in 1589) would have been somewhat stunted by the subsequent turmoil in Russia, it did not wholly disappear. When Nikon became active in promoting Ukrainian and (at least individual) Greek singers in the 1650s, a period during which Paul tells us that some sort of Greek singing style was customary in Ukraine, the style (or at least the label) would have been familiar.

Paul's references to recitations or to singing in Greek reveal another layer of Orthodox musical practice in both Ukraine and in Muscovy, for one of the places practicing the "customary" Greek singing was a convent. There were no women among the singing ensembles at the tsars' or the patriarchal courts, but Paul's several trips to Ukrainian and Muscovite convents-wholly out of bounds to non-Orthodox visitors-reveal the nuns' lively participation in liturgical singing as well as in the extensive extra-liturgical singing for processions, banquets, and the like. In one of Paul's descriptions of a visit to the large and wealthy Novodevichii Convent just outside Moscow, he shows us that the nuns performed in many of the ways we have observed the pevchie d'iaki singing. Paul apparently describes antiphonal singing, referring to two separate singing groups, which would suggest trained, specialist singers: ${ }^{59}$

On our arrival at the convent, they [the nuns] all came out to meet us; and then walked before us, chaunting with a melody that charmed the heart, until he [Patriarch Makarios] had ascended to the church. Whilst we paid our devotions to the images, they sang the Axión estin; and delightful was

58 On grecheskii rospev, see Igoshev 1992 and Keldysh 1983, 218-19. Parfent'ev 1991, 85 and n. 122, notes the presence of the Patriarch of Serbia in Moscow in the mid-1650s, when Patriarch Makarios of Antioch was there, and cites RGADA, f. 235, op. 2, No. 38, indicating that singers associated with both patriarchs sang for Patriarch Nikon in Greek. Although Russian sources refer to Gabriel as a patriarch (for example Dvortsovye razriady 1852, 457-59), Paul of Aleppo considered him an impostor, calling him "the pretended Patriarch" and noting pointedly that he was seated "at a distant table" at a banquet in the Tsar's presence; Paul's party was seated with other important clerics in the middle of the hall (Balfour $1829-36,1: 388-89$, and see also $1: 382-83)$.

59 Balfour 1829-36, 2:272 (during Lent 1656). Nuns of the Convent of St. Savvas also sang accompanying the procession of the Patriarchal party; see Balfour 1829-36, 2:167-68 and Murkos 1898 no. 4:51. In both passages, Paul specifies that these were "Russian, that is, Cossack Nuns" (as opposed to Muscovite nuns; Balfour 1829-36, 2:167 and cf 2:271-72, and see also the note in Murkos 1898 no. 4:55). Senyk 1983, 175-76 (using Murkos), also notes the implications of antiphonal singing in Paul's writing. 
the harmony and sweetness of their tones and voices, which they continued to modulate, till the Patriarch had given to all of them his benediction, one by one. Then we put on our copes in the Narthex, and the young ladies began the Hours. They chaunted also the responses of the Mass, in two choirs ....

The nuns then accompanied the patriarchal party to the meal, during which one of the women read from the Gospels.

The male singers also performed at convents, for example at a funeral held at Novodevichii. ${ }^{60}$ Yet a later document shows us that the nuns were fully capable of singing liturgical music on their own, without participation by the male singers. This reference again comes from Novodevichii Convent, to which Sofiia Alekseevna, daughter of Tsar Aleksei Mikhailovich and half-sister of Peter the Great, was confined in 1689. A decade later, in 1698, when Peter received information indicating that Sofiia was involved in an uprising by the musketeers, security around her was tightened, and she was finally forced to take her vows as a nun. Peter was concerned with isolating her entirely, and his efforts included the male singers who had performed in liturgical services at the great convent; to this end, he directed in October 1698 that "no choristers [pevchie] should be admitted to the monastery. The nuns sing well enough."61

Other evidence of musical literacy at Novodevichii supports Paul's observations. An Irmologii written in staff notation by one of the nuns at the convent is dated 1660 (a fairly early example of staff notation in Muscovy), and the extant collection from the convent includes other manuscripts using staff notation. ${ }^{62}$ Other sources suggest a familiar organization of singers at the convent. Early in the seventeenth century, payment records refer to groups of "bol'shie kryloshanki" and "men'shie kryloshanki" (greater and lesser female singers at the kliros), which suggests a division of duties or experience reflected in the different pay scales. ${ }^{63}$

Paul's enthusiasm for the nuns' singing, plus his appreciation of Ukrainian singing styles, reached a fever pitch in his description of Ukrainian nuns at the

60 Balfour 1829-36, 2:82-83, describes the funeral. He also apparently refers to male singers at the Feast of the Translation of the Image of Our Lady of Smolensk in 2:165-66. These passages are in Murkos 1898 no. 3:166-67 and 1898 no. 4:49.

61 Quoted and translated in Hughes 1990, 255, citing Pis'ma i bumagi Imperatora Petra Velikogo 1887, 268 (document No. 254): “A pev"chikh v monastyr' ne puskat': a poiut i staritsy khorosho ..."

62 The source is GIM, 104027 NDM 122, with the inscription (fol. 3) reading (in part): "[copied] by means of the diligence and labor of nuns from this same [Novodevichii] convent" ("Tshchaniem $i$ trudom togo zhe monastyria inokin"); the full inscription is cited in Chistiakova 2000, 151. A color facsimile of another staff-notated Irmologii (1667) from the collection is in Trutneva and Shvedova 1988, 96 (No. 56, identified on p. 111 as NDM 123/457, from the "[m] anuscript workshop of the Novodevichy Convent"). Other, unspecified, notated Irmologie written at the convent are mentioned in Shvedova 1998, 83, where Paul of Aleppo's comments on the women singing there are also noted. Findeizen 1928, 1:334, states that Tsarevna Sofiia, as the nun Susanna, copied a notated Oktoechos; he cites Kazanskii 1847, 57, which was not available for the present study (and was not mentioned in Hughes 1990).

63 Shvedova 1998, 78, identifies them as singers, citing a document from 1603-04. The term kryloshanka or kryloshanin, in early usage, is somewhat unclear; see Morosan 1986, 9-10, who discusses it only in terms of males. 
Convent of the Divine Ascension, where he describes the nuns singing at Divine Liturgy (many of them, apparently, were from Polish families): ${ }^{64}$

As soon as we had entered it, the Nuns began to sing 'Aksión estin etc. and all the Prayers and Responses of the Mass ... they attended to the mass, now begun by their Chaplain ... Presently they commenced singing and chaunting, with a sweet voice and tune which affected the heart and drew tears from the eyes: it was a soothing searching melody, greatly to be admired above the chaunting of men. There was a softness in their intonation quite new to us; and we were particularly delighted with the voices of the young girls, both great and small. ... The Hágios and Halleloúïa, and Kýrie elééson, they chaunted as with one voice; and one of them read the Epistles very clearly and distinctly. They chaunted the Psalms also, and the Prokeimenon, with a peculiar melody.

The Orthodox visitors to the Tsars' courts, like the travelers from the West, were in some ways strangers in a strange land, struggling to comprehend the vast landscapes and cities, the great wealth and piety they saw around them. But their contact with clerics through all ranks of Russian clergy, their participation in the majestic events of the church, and the common cultural currency they shared with their hosts make these Orthodox travelers valuable witnesses to the musical practices of late sixteenth- and seventeenth-century Muscovy. They were, for the most part, welcomed and honored guests, with entree into the churches, monasteries, and even the convents of Russia. Their informed observations, based on their rich experience and active engagement in virtually every level of church ceremony, afford a unique perspective of the lives and experiences of the liturgical singers and instrumentalists of Muscovy.

\section{REFERENCE LIST}

Alexandropoulou, Olga. 1989-90. “The History of Russia in Works by Greek Scholars of the Seventeenth Century." Cyrillomethodianum 13-14:61-91.

Arkhiv iugo-zapadnoi Rossii. 1872. Vol. 5, pt. 1. Kiev: Komissiia dlia razbora drevnikh aktov.

Balfour, F. C. 1829-36. The Travels of Macarius, Patriarch of Antioch: written by his attendant Archdeacon Paul of Aleppo. Translated and ed. by F. C. Balfour. 2 vols. London: Printed for the Oriental Translation Committee.

Barbour, Philip. 1966. Dimitry Called the Pretender: Tsar and Great Prince of All Russia, 1605-1606. Boston: Houghton Mifflin and Cambridge, Massachusetts: Riverside Press.

Belkin, A. A. 1975. Russkie skomorokhi. Moscow: Nauka.

Bestuzhev-Riumin, K. N. 1883. Pamiatniki diplomaticheskikh snoshenii moskovskogo gosudarstva s Angliei, vol. 2 of Pamiatniki diplomaticheskikh snoshenii drevnei Rossii s derzhavami inostrannymi. St. Petersburg: Tip. V. S. Balasheva. 
Bubnov, N. Iu. 1993. "Nikon." Slovar' knizhnikov i knizhnosti drevnei Rusi, XVII v., pt. 2:400-04. St. Petersburg: Dmitrii Bulanin.

Buganov, V. I. and Lukichev, M. P., eds. 1988. Posol'skaia kniga po sviaziam Rossii $s$ Gretsiei (pravoslavnymi ierarkhami i monastyriami). Moscow: AN SSSR.

Bulanin, D. M., ed. 1995. Dnevnik Mariny Mnishek. Translated by V. N. Kosliakov, commentary by A. A. Sevast'ianova. St. Petersburg: Dmitrii Bulanin. . 2004a. "Meletii Grek." Slovar' knizhnikov i knizhnosti drevnei Rusi, XVII v., pt. 4:494-96. St. Petersburg: Dmitrii Bulanin.

.2004b. "Nikon." Slovar' knizhnikov i knizhnosti drevnei Rusi, XVII v., pt. 4:757-61. St. Petersburg: Dmitrii Bulanin.

Burilina, E. L. 1984. "Chin 'za prilivok o zdravii gosudaria"' Drevnerusskaia literatura: Istochnikovedenie, ed. D. S. Likhachev, 204-14. Leningrad: Nauka.

Bussov, Konrad. 1961. Moskovskaia khronika [Die Moskauer Chronik], 15841613. Translated and ed. by I. I. Smirnov. Moscow and Leningrad: Izd. Akademii nauk SSSR.

Bussow, Conrad. 1994. The Disturbed State of the Russian Realm. Translated and ed. by G. Edward Orchard. Montreal: McGill-Queen's University Press.

Chistiakova, M. V. 2000. Monakhini 's Beloi rosi'v Novodevichem monastyre. In Trudy Gosudarstvennogo istoricheskogo muzeia 116. Moscow: Gos. istoricheskii muzei.

Collins, Samuel. 1671. The Present State of Russia, In a Letter to a Friend at London; Written by an Eminent Person residing at the Great Czars Court at Moscow for the space of nine years. London: Printed by John Winter.

Demetrakopoulos, Photios A. 1981. "On Arsenios, Archbishop of Elasson." Byzantinoslavica 42, fasc. 2:145-53.

. 1984. Arsénios Elassónos (1550-1626). Bíos kaí Ergo: Symbolē stē melétē tôn metabyzantinôn logiōn tês Anatolês (Arsenios of Elasson (1550-1626). Life and work: Contribution to the study of post-Byzantine literati of the East). Athens: Imago.

Dmitrievskii, A. 1899. Arkhiepiskop elassonskii Arsenii i memuary ego iz russkoi istorii. Kiev: Tip. Imp. universiteta sv. Vladimira.

Dopolneniia $k$ Aktam istoricheskim. 1846. Vol. 2. St. Petersburg: V Tip. II Eduarda Pratsa.

Dvortsovye razriady. 1850. Vol. 1. St. Petersburg: V Tip. II Otdeleniia Sobstvennoi Ego Imperatorskogo Velichestva kantseliarii.

. 1852. Vol. 3. St. Petersburg: V Tip. II Otdeleniia Sobstvennoi Ego Imperatorskogo Velichestva kantseliarii.

Findeizen, Nikolai. 1928. Ocherki po istorii muzyki v Rossii. Vol. 1. Moscow: Gosudarstvennoe izdatel'stvo Muzsektor.

Fonkich, B. L. 1977. Grechesko-Russkie kul'turnye sviazi v XV-XVII vv. Moscow: Nauka.

Gardner, I. A [Johann von]. 1978. Bogosluzhebnoe penie russkoi pravoslavnoi tserkvi. Vol. 1. Jordanville, New York: Holy Trinity Russian Orthodox Monastery. 
Gardner, Johann von. 1980. Russian Church Singing. Vol. 1, Orthodox Worship and Hymnography. Translated by Vladimir Morosan. Crestwood, New York: St. Vladimir's Seminary Press.

Germanos, Bishop of Sardeis. 1945. "The Russian Patriarchate: Foundation of the Patriarchate of Moscow; Official Ecclesiastical Documents." Orthodoxia 20, No. 2-3 (February-March):27-34.

Gritsopoulos, Tasos A. 1965. "Hierótheos. Mētropolítēs Monemvasías" (Hierotheos. Metropolitan of Monemvasia). Thrēskeutikē kai Ëthikē Enkyklopaideía. Vol. 6:cols. 796-98. Athens: A. Martinos.

Gudziak, Borys. 1995. "The Sixteenth-Century Muscovite Church and Patriarch Jeremiah II's Journey to Muscovy, 1588-1589: Some Comments concerning the Historiography and Sources." Harvard Ukrainian Studies 19:200-25.

. 1996. "The Creation of the Moscow Patriarchate: A Prelude to Patriarchal Reforms in the Kyivan Metropolitanate Preceding the Union of Brest (1595-1596)." Logos: A Journal of Eastern Christian Studies 37, nos. 1-4:219-71.

1998. Crisis and Reform: The Kyivan Metropolitanate, the Patriarchate of Constantinople, and the Genesis of the Union of Brest. Cambridge, Massachusetts: Distributed by Harvard University Press for the Ukrainian Research Institute, Harvard University.

Halperin, Charles J. 1997. "In the Eye of the Beholder: Two Views of seventeenthcentury Muscovy." Russian History / Histoire Russe 24, no. 4:409-23.

. 1998-99. "Friend and Foe in Paul of Aleppo's Travels of Patriarch Macarios." Modern Greek Studies Yearbook 14-15:97-114.

"Hermogen." 1979. Modern Encyclopedia of Russian and Soviet History. Vol. 14:11-13. Gulf Breeze, Florida: Academic International Press.

Hirschberg, Aleksander. 1899. Pamiętnik Stanisława Niemojewskiego. Lwow: Nakładem zakładu n. im. Ossolińskich.

Hotson, Leslie. 1954. The First Night of Twelfth Night. New York: Macmillan.

Hughes, Lindsey. 1990. Sophia Regent of Russia: 1657-1704. New Haven: Yale University Press.

Igoshev, L. A. 1992. "Proiskhozhdenie grecheskogo rospeva (opyt analiza)." Pamiatniki kul'tury: Novye otkrytiia 1992 (1993):147-50.

Isaevych, Ia. D. 1966. Bratstva ta ïkh rol'v rozvytku ukraïns'koï kul'tury XVIXVIII st. Kiev, Naukova dumka.

Ivakin, I. 1891. “Opisanie puteshestviia pol'skogo posol'stva v Moskvu v 1678 godu." Chteniia v Imperatorskom obshchestve istorii i drevnostei rossiiskikh pri Moskovskom universitete 3:pt. 3:iii-202.

Kapterev, N. F. 1895. "Snosheniia ierusalimskikh patriarkhov s russkim pravitel'stvom s poloviny XVI do kontsa XVIII stoletiia." Pravoslavnyi palestinskii sbornik 15, vypusk 1 (entire volume).

Karmiris, Ioannis N. 1965. "Hieremías. Ho B'. Patriárchēs Kōnstantinoupóleōs” (Hieremias. II. Patriarch of Constantinople). Thrēskeutikē kaì Ëthikē Enkyklopaideía. Vol. 6:cols. 780-84. Athens: A. Martinos.

Kazanskii, P. 1847. Selo Novospasskoe, Dedenovo tozh i rodoslovnaia Golovinykh. Moscow: Izd. G. P. Golovina. 
1848. "Ispravlenie tserkovno-bogosluzhebnykh knig pri patriarkhe Filarete." Chteniia v Imperatorskom obshchestve istorii i drevnostei rossiiskikh pri Moskovskom universitete 8:pt. 1:1-26.

Kechagioglou, G. 2001. Pezographikē Anthología: Aphēgēmatikós graptós neoellēnikós lógos (Anthology of prose: Aphoristic written modern Greek prose). Vol. 1:227-233. Apó ta télè tou Byzantíou ōs tē Gallikē Epanástasē (From the end of Byzantium to the French Revolution).Thessaloniki: AUTh/ Institute of Modern Greek Studies [M. Triantaphyllides Foundation].

Keep, J. L. H. 1959-60. "The Régime of Filaret, 1619-33." Slavonic and East European Review 38:334-60.

Keldysh, Iu. V. 1983. Drevniaia Rus' XI-XVII veka. Vol. 1 of Istoriia russkoi muzyki v desiati tomakh. Moscow: Muzyka.

Kharlampovich, K. V. 1968. Malorossiiskoe vliianie na velikorusskuiu tserkovnuiu zhizn'. 1914. Reprint, The Hague: Slavistic Printings and Reprintings, No. 119 , ed. C. H. van Schooneveld.

Knös, Börje. 1962. "Une version grecque de l'histoire du Faux Démétrius, Tzar de la Russie." Deltion tês Historikês kaí Ethnologikês Hetaireías tês Helládos 16:223-66.

Kolesov, V. V. and V. V. Rozhdestvenskaia. 2000. Domostroi. St. Petersburg: Nauka.

Konstantinidis, Ioannis Ch. 1965. "Iōakeím. Ho E'. Patriárchēs Antiocheías" (Ioakeim. V. Patriarch of Antioch). Thrēskeutikē kai Ëthikē Enkyklopaideía. Vol. 6:cols. 1095-96. Athens: A. Martinos.

Koshelev, V. V. ed. 1994. Skomorokhi: Problemy i perspektivy izucheniia (K 140letiiu so dnia vykhoda pervoi raboty o skomorokhakh). St. Petersburg: Rossiiskii institut istorii iskusstv.

Kotliarchuk, A. S. 2001. Prazdnichnaia kul'tura v gorodakh Rossii i Belorussii XVII veka: ofitsial'nye tseremonii i krest'ianskaia obriadnost'. St. Petersburg: Peterburgskoe Vostokovedenie.

Krajcar, Jan. 1967. "Religious Conditions in Smolensk, 1611-1654." Orientalia Christiana Periodica 33, fasc. 2:404-56.

Kriaras, Emmanouel. 1977. Lexikó tēs Mesaiōnikēs Hellēnikēs Dēmōdous Grammateías (1100-1669) (Lexicon of medieval Greek folk literature). Vol. 5. Thessaloniki: [n.p.].

Lapteva, L. P. 1970. "Rasskaz ochevidtsa o zhizni Moskovii kontsa XVII veka." Voprosy istorii 1:103-26.

Lassithiotakis, Michel. 1996. "La 'Vie de Dimitri' de Matthieu Politis (1606), ou L'Histoire Allégorisée." Revue des Études Néo-helléniques 5, No. 2:177-204.

Lebedeva, I. N. 1968. "Pozdnie grecheskie khroniki i ikh russkie i vostochnye perevody." Palestinskii sbornik 18 (81):3-139 (entire volume).

Legrand, Émile. 1963. Bibliographie Hellénique ou Description Raisonnée des Ouvrages Publiés par des Grecs au dix-septième siècle. 4 vols. 1894-1903. Reprint, Brussels: Culture et Civilisation.

Leonid, Archimandrite. 1874. "Istoricheskoe opisanie stavropigial'nogo Voskresenskogo Novyi Ierusalim imenuemogo monastyria." Chteniia v Im- 
peratorskom obshchestve istorii i drevnostei rossiiskikh pri Moskovskom universitete 3:pt. 1:i-iv, 1-124.

1883. "Svedenie o slavianskikh pergamennykh rukopisiakh, postupivshikh iz knigokhranilishcha Sviato-Troitskoi Sergievoi Lavry v biblioteku Troitskoi Dukhovnoi seminarii v 1747." Chteniia v Imperatorskom obshchestve istorii i drevnostei rossiiskikh pri Moskovskom universitete 2:pt. 2:81-167.

Liberman, A., B. Morosov, and S. Shokarev, eds. 1998. Khroniki smutnogo vremeni. In Istoriia Rossii i doma Romanovykh $v$ memuarakh sovremennikov. $X V I I-X X v v$. Moscow: Fond Sergeia Dubova.

Likhachev, D. S., A. M. Panchenko, and N. V. Ponyrko. 1984. Smekh v drevnei Rusi. Leningrad: Nauka.

Lyseck, Adolf. 1828. "Posol'stvo Battoni ot avstriiskogo Imperatora Leopol'da k Tsariu Alekseiu Mikhailovichu v 1675 godu." Otechestvennye zapiski 35 (September, No. 101):301-32.

Makarii, Metropolitan. 1883-1903. Istoriia russkoi tserkvi. 12 vols. St. Petersburg: var. eds. Pechatnia R. Golike.

Medlin, William K. and Christos G. Patrinelis. 1971. Renaissance Influences and Religious Reforms in Russia: Western and Post-Byzantine Impacts on Culture and Education (16th -17th Centuries). Geneva: Librairie Droz.

Metallov, V. M. 1915. Ocherk istorii pravoslavnogo tserkovnogo peniia $v$ Rossii. Moscow: A. I. Snegirev.

Miege, Guy. 1669. A Relation of Three Embassies from his sacred Majestie Charles II to the Great Duke of Muscovie, the King of Sweden, and the King of Denmark. Performed by the Right Ho-ble the Earle of Carlisle in the years 1663 and 1664. London: Printed for John Starkey.

Morosan, Vladimir. 1979. "Penie and Musikiia: Aesthetic Changes in Russian Liturgical Singing during the Seventeenth Century." St. Vladimir's Theological Quarterly 23, nos. 3-4:149-79.

1986. Choral Performance in Pre-Revolutionary Russia. Russian Music Studies 17. Ann Arbor: UMI Research Press.

Murkos, G. 1897-98. "Puteshestvie Antiokhiiskogo patriarkha Makariia." Chteniia $v$ Imperatorskom obshchestve istorii i drevnostei rossiiskikh pri Moskovskom universitete 4 (1897), pt. 3:i-viii, 1-202; 3 (1898), pt. 3:i-iv, 1-208; 4 (1898), pt. 2:i-ix, 1-195.

Nikolaevskii, P. 1879. "Uchrezhdenie patriarshestva v Rossii." Khristianskoe chtenie No. 11-12:552-81.

Oikonomidou, D. B. 1959. "Chronográphou toû Dōrothéou tà Laographiká" (The Laographica by the Chronographer Dorotheos). Laographiká 18:11652.

Orlov, A. 1913. "Chashi gosudarevy." Chteniia v Imperatorskom obshchestve istorii i drevnostei rossiiskikh pri Moskovskom universitete 4:part 2:1-69.

Papadopoulos, Chrysostomos. 1907. Hoi patriárchai Hierosolýmōn hōs pneumatikoi cheiragōgoi tês Rosías katá tón IZ' aiôna (The Patriarchs of Jerusalem as spiritual leaders of Russia during the $17^{\text {th }}$ century). Jerusalem: Typois hierou koinou tou Panagiou Taphou. 
Papadopoulos-Kerameus, Athanasios. 1963. Análekta Hierosolymitikês Stachyologías: Syllogē Anekdótōn kaì Spaniōn Hellēnikôn Syngraphôn perì tôn katà tên Heōian Orthodóxōn Ekklēsiôn kai málista tês tôn Palaistinôn (Analecta Selected from Jerusalem: Collection of unpublished and rare Greek documents about the Orthodox Churches of the East and particularly that of Palestine). 1891. Reprint, Brussels: Culture et Civilisation.

Papoulidis, Constantine. 1974. "A Second Greek Account of the Revolution of A) Pseudo-Dmitriy (Russia, 1605-1606): Codex Iviron 710, ff. 100"rv" Balkan Studies 15:288-97.

Parfent'ev, N. P. 1991. Professional'nye muzykanty rossiiskogo gosudarstva XVI-XVII vekov. Cheliabinsk: Izd-vo Cheliabinskogo poligr. ob"edineniia "Kniga."

Pasinus, Josephus, Antonius Rivautella, and Franciscus Berta. 1749. Codices Manuscripti Bibliothecae Regiae Taurinensis Athenaei. Turin: Typographia Regia.

Pis'ma i bumagi Imperatora Petra Velikogo. 1887. Vol. 1. St. Petersburg: Gosudarstvennaia tipografiia.

Pitirim, Episkop. 1968. "Arsenii, Arkhiepiskop elassonskii: Opisanie puteshestviia, predpriniatogo Ieremiei vtorym, Patriarkhom konstantinopol'skim, v Moskoviiu, i uchrezhdeniia moskovskogo patriarshestva." Bogoslovskie trudy 4:251-79.

Platonov, S. F. 1970. The Time of Troubles. Translated by John T. Alexander. Lawrence, Kansas: University Press of Kansas.

Protopopov, V. V. 1976. "Notnaia biblioteka Tsaria Fedora Alekseevicha." Pamiatniki kul'tury: Novye otkrytiia 1976 (1977):119-33.

Radu, Basile. 1949. "Voyage du Patriarche Macaire d'Antioche: Texte arabe et traduction française." Patrologia Orientalis 26, fasc. 5:603-720.

Russkaia istoricheskaia biblioteka. 1875. Vol. 2. St. Petersburg: V Tip. Panteleevykh.

Sathas, K. N. 1868. Neoellēnikē Philología: Biographíai tôn en toîs Grámmasi Dialampsántōn Hellēnōn, apò tês kalalýseōs tês Byzantinês Autokratorías méchri tês Hellēnikês ethnegersías (1453-1821) (Modern Greek Philology: Biographies of the Greek literary luminaries, from the demise of the Byzantine Empire to the Greek War of Independence). Athens: Ek tes typographies ton teknon Andreou Koromela.

. 1979. Biographikón Schedíasma perí toû Patriárchou Hieremíou B' (1572-1594) (Biographical sketch of Patriarch Hieremias II (1572-1594)). 1870. Reprint, Thessaloniki: Pan. S. Pournaras Editions.

Senyk, Sophia. 1983. Women's Monasteries in Ukraine and Belorussia to the Period of Suppressions. Orientalia Christiana Analecta 222. Rome: Pont. Institutum studiorum orientalium.

Shusherin, I. K. 1871. Izvestie o rozhdenii i vospitanii i o zhitii sviateishego Nikona Patriarkha Moskovskogo i vseia Rossii. Moscow: Univ. tipografiia.

Shvedova, M. M. 1998. “Tsaritsy-inokini Novodevich'ego monastyria." In Novodevichii monastyr'v russkoi kul'ture: Materialy nauchnoi konferentsii $1995 \mathrm{~g}$. 
Ed. V. L. Egorov, 73-93. (Vol. 99 of Trudy Gosudarstvennogo istoricheskogo muzeia.) Moscow: Gos. istoricheskii muzei.

Sobranie gosudarstvennykh gramot i dogovorov. 1822. Vol. 3. Moscow: V Tip. S. Selivanskogo.

Sokolova, L. V. 1989. "Chasha gosudareva zazdravnaia." Slovar' knizhnikov $i$ knizhnosti drevnei Rusi, vtoraia polovina XIV-XVI v., pt. 2:508-11. Leningrad: Nauka.

Sparwenfeld, Johan. 2002. J. G. Sparwenfeld's Diary of a Journey to Russia 168487. Ed. Ulla Birgegård. Slavica Suecana, Series A: Publications, vol. 1. Stockholm: Kungl. Vitterhets Historie och Antikvitets Akademien.

Sreznevskii, I. I. 1958. Materialy dlia slovaria drevnerusskogo iazyka. 3 vols. 18931903. Reprint, Moscow: Gos. izdatel'stvo inostrannykh i natsional'nykh slovarei.

Stadnicki, Martyn. 1906. "Istoriia Dimitriia Tsaria moskovskogo i Mariny Mnishek, docheri sendomirskogo voevody." Translated by A. Titov. Russkii arkhiv 2:129-74 and 177-222.

Stanitsas, S. 1985-86. “To Chronikó tou 1570 kai oi parallagés tou: Ta Chroniká tou Pseudodōrótheou kai Manouēl Malaxoú" (The Chronicle of 1570 and its variants: The Chronicles of Pseudodorotheos and Manuel Malaxos). Peloponnēsiaká 16:593-633.

Staurakopoulou, Soteria. 2003. "Stoixeía poiētikēs stē Chronographía tou Pseudodōrótheou: mia aphēgēmatologikē kai ermēneutikē proséngisē" (Elements of poetics in the Chronography of Pseudodorotheos: A Narratological and hermeneutic approach). Ph.D. diss., Aristotle University of Thessaloniki.

Tanner, Bernard. 1689. Legatio Polono-Lithuanica in Moscoviam. Nuremberg: Johannis Ziegerl.

Thyrêt, Isolde. 2001. Between God and Tsar: Religious Symbolism and the Royal Women of Muscovite Russia. DeKalb, Illinois: Northern Illinois University Press.

Titov, A. A. 1907. “Zapiski Stanislava Nemoevskogo (1606-1608)." Rukopisi slavianskie i russkie, prinadlezhashchie I. A. Vakhrameevu 6:section 2:i-xii, 1-292.

Trutneva, N. F. and M. M. Shvedova. 1988. Novodevichii monastyr'/ The Novodevichy Convent. Moscow: Sovetskaia Rossiia.

Uspenskii, B. A. 1997. "Svad'ba Lzhedmitriia." Trudy Otdela drevnerusskoi literatura Instituta russkoi literatury 50:404-25.

Ustrialov, N. 1834. Dnevnik Mariny Mnishek i poslov pol'skikh. Part 4 of Skazaniia sovremennikov o Dimitrii Samozvantse. St. Petersburg: V Tip. Imper. rossiiskoi akademii.

Waugh, Daniel Clarke. 1981. Review of Grechesko-Russkie kul'turnye sviazi v $X V-X V I I v v$., by B. L. Fonkich. Russian History/Histoire Russe 8, pt. 3:41416.

Wichmann, Burchard Heinrich von. 1820. Sammlung bisher noch ungedruckter kleiner Schriften zur ältern Geschichte und Kenntnis des Russischen Reichs. Vol. 1. Berlin: [n.p.]. 
Yurchyshyn-Smith, Oksana. 2004. "The Antimension (1620) of Theophanes, Patriarch of Jerusalem." Oriens Christianus 88:93-110.

Zabelin, I. E. 1872. "Okhotnichii dnevnik Tsaria Alekseia Mikhailovicha 1657 goda." In Opyty izucheniia russkikh drevnostei $i$ istorii. Issledovaniia, opisaniia i kriticheskie stat'i, 281-300. Moscow: Tip. Gracheva.

Zachariadou, E. A. 1961. "Mía italikē pēgē toû Pseudodōrothéou già tēn historía tôn Othōmanôn" (An Italian source of Pseudodorotheos for the history of the Ottomans). Peloponnēsiaká 5:46-59.

. 1962. "Hē patriarcheía toû Dionysíou $B$ ' sè mía parallagē toû Pseudodōrothéou" (The patriarchy of Dionysios II in a variant of Pseudodorotheos). Thesaurísmata 1:142-161.

Zampelios, Spyridon. 1983. Kathídrysis Patriarcheíou en 'Rōssíai (The Founding of the Patriarchate in Russia). 1859. Reprint, Athens: Dionysios N. Karavias Bookstore.

Zaviras, Georgios I. 1972. Nèa Hellás (Modern Greece). 1872. Reprint, edited, with introduction and index, by Tasos A. Gritsopoulos. Athens: [n.p.].

Zenkovsky, Serge A. 1974. Medieval Russia's Epics, Chronicles, and Tales. Revised ed. New York: Dutton.

Zilitinkevich, V. S. 1992. "Arsenii Elassonskii." Slovar' knizhnikov $i$ knizhnosti drevnei Rusi, XVII v., pt. 1:108-10. St. Petersburg: Dmitrii Bulanin.

Zvereva, S. G. 1987. "O khore gosudarevykh pevchikh d'iakov v XVI v." Pamiatniki kul'tury: Novye otkrytiia 1987 (1988):125-30.

. 1989. "Gosudarevy pevchie d'iaki posle 'Smuty." Germenevtika drevnerusskoi literatury 2:355-82.

\section{ABSTRACT}

Greek and other Orthodox travelers to Russia were important and knowledgeable witnesses to Muscovite liturgical singing practices. This article surveys several Greek sources from around 1600: a poem and a memoir by Archbishop Arsenios of Elasson (1550-1626); a poem describing events connected with the False Dmitrii (1606) by Matthaios Koletzides; and a report of the Moscow trip undertaken by Theophanes, Patriarch of Jerusalem (1619). We also consider the lengthy narrative by Paul of Aleppo, who accompanied Patriarch Makarios of Antioch to Moscow (1650s and 1660s). All of these sources provide rich examples of continuing exchanges among Russian and foreign Orthodox singers throughout this period.

\section{RÉSUME}

Les voyageurs orthodoxes en Russie, grecs ou autres, comptent parmi les plus importants témoins au fait des pratiques de chants liturgiques moscovites. Cet article étudie plusieurs sources grecques des années 1600 : un poème et un mémoire de larchevêque Arsenios d'Elasson (1550-1626); un poème de Matthaios Koletzides décrivant les événements en relation avec le Faux Dmitrii (1606); enfin, un rapport du voyage à Moscou entrepris par Théophane, Patriarche de Jérusalem (1619). Nous avons également pris en considération la longue narration de Paul d'Aleppe, qui accompagna le Patriarche Maka- 
rios d'Antioche à Moscou (dans les années 1650 et 1660). Toutes ces sources représentent de riches exemples des échanges permanents entretenus entre les chanteurs orthodoxes russes et étrangers pendant cette période. 